GLOBAL WATER PATHOGEN PROJECT

PART THREE. SPECIFIC EXCRETED PATHOGENS: ENVIRONMENTAL AND EPIDEMIOLOGY ASPECTS

\title{
ROTAVIRUS AND ASTROVIRUS
}

\section{Marcelle da Silva}

Instituto Oswaldo Cruz

Rio de Janeiro, Brazil

\section{Matias Victoria}

Universidad de la Republica

Salto, Uruguay

Marize Miagostovich

Instituto Oswaldo Cruz

Manguinhos, Brazil 


\section{Copyright:}

\section{cc) (i) (2) \\ BY SA}

This publication is available in Open Access under the Attribution-ShareAlike 3.0 IGO (CC-BY-SA 3.0 IGO) license (http://creativecommons.org/licenses/by-sa/3.0/igo). By using the content of this publication, the users accept to be bound by the terms of use of the UNESCO Open Access Repository (http://www.unesco.org/openaccess/terms-use-ccbysa-en).

\section{Disclaimer:}

The designations employed and the presentation of material throughout this publication do not imply the expression of any opinion whatsoever on the part of UNESCO concerning the legal status of any country, territory, city or area or of its authorities, or concerning the delimitation of its frontiers or boundaries. The ideas and opinions expressed in this publication are those of the authors; they are not necessarily those of UNESCO and do not commit the Organization.

\section{Citation:}

da Silva, M., Victoria, M. and Miagostovich, M. (2016). Rotavirus and Astroviruses. In: J.B. Rose and B. Jiménez-Cisneros, (eds) Water and Sanitation for the 21st Century: Health and Microbiological Aspects of Excreta and Wastewater Management (Global Water Pathogen Project). ((J.S Meschke, and R. Girones (eds), Part 3: Specific Excreted Pathogens: Environmental and Epidemiology Aspects - Section 1: Viruses), Michigan State University, E. Lansing, MI, UNESCO. https://doi.org/10.14321/waterpathogens.18

Acknowledgements: K.R.L. Young, Project Design editor; Website Design: Agroknow (http://www.agroknow.com)

Last published: October 5, 2016 


\section{Summary}

Despite all progress obtained in relation to environmental sanitation in the last century, the number of cases of diarrheal disease or acute gastroenteritis resulting from consumption of contaminated water supplies and sanitation deficiencies are alarming. Currently, diarrheal disease still represents the fourth leading cause of death among children under five years old and viruses represent a large part of etiologic agents. Species A rotaviruses (RVA) are the main etiologic agent of diarrheal disease in children worldwide and are recognized as important environmental contaminants typically found in high concentration in different matrices. There is estimated that global RVA emissions is about $2 \times 10^{18}$ viral particles/year, of which $87 \%$ is produced by the urban population. Infected people may excrete $10^{10}-10^{12}$ viral particles per gram and/or milliliter of stool. And dose-response models show that RVA is one of the most infectious virus, with $\mathrm{ID}_{50}$ of about 6 viral particles.

They can remain in the environment for days or months maintaining their viability at low temperatures $\left(4^{\circ} \mathrm{C}-20^{\circ} \mathrm{C}\right)$ and $\mathrm{pH}$ around 3.0 . The RVA is also relatively stable to inactivation and remain on porous particle surfaces (paper and cotton cloth) and nonporous (aluminum, latex).

RVA is a member of the Reoviridae family, and the genome consists of 11 double-stranded RNA gene segments encoding six structural (VP1-4, VP6-VP7) and six nonstructural proteins (NSP1-6). RVA has been classified by different systems: a dual classification system based on the two genes that encode the outer capsid proteins, VP4 (P-genotype) and VP7 (G-genotype) and a new classification system including all 11-gene segments. The high morbidity and mortality of RVA, mostly in developing countries, encouraged the development of RVA vaccines in the last decades. Two vaccines, Rotarix ${ }^{\circledast}$ (RV1, GlaxoSmithKline, Brentford, Middlesex, UK) and RotaTeq ${ }^{\circledR}$, are licensed in several countries and both have demonstrated broad protection against each of the most common RVA genotypes. Studies conducted in countries where RVA vaccine is provided in their national immunization programs (NIP) show the reduction of diarrheal disease caused by these viruses in vaccinated children. However, even after vaccination programs, RVA are detected in high concentrations in wastewater, with high morbidity levels. In some countries, environmental approach has complemented molecular epidemiology studies targeting the acknowledgement of the RVA genotypic.

Among other causative viruses of diarrheal disease are the human astroviruses (HAstV), which also represent important environmental biological contaminants. High levels of HAstV in sewage treatment plants, ranging from $43-100 \%$ in effluent and $82.3 \%$ in influent have been demonstrated. HAstV are stable at $\mathrm{pH} 3.0$ and resistant to a wide variety of detergents and lipid solvents. They keep their viability after 5 minutes at $60^{\circ} \mathrm{C}$ and also when stored at $-80^{\circ} \mathrm{C}$ for a period of 10 years, but they are unstable to undergo thawing (KURTZ \& Lee, 1987; MATSUI \& Greenberg, 2001).

HAstV belong to the Astroviridae family, are non-enveloped, single-stranded, positive-sense, polyadenylated RNA viruses and are divided into eight genotypes. In general, HAstV-1 is the most common in children, but the predominant genotype can vary according to geographic area, as well the environmental dissemination. Originally astroviruses were classified into genera (Mamastrovirus and Avastrovirus) and species based only on the host of origin. However, since 2011, the classification is based on the full length amino acid sequence of the ORF2 capsid region the most variable region of the genome. This new classification divides the Mamastrovirus genus into two genogroups (G), GI and GII, with 10 and 9 species, respectively, both comprising viruses from human and animal origin. Mamastrovirus species 1 (MAstV1; GI.A) includes HAstV 1 to 8 (classic HAstV) and species 6 (MAstV6; GI.F) MLB1 (AstV-MLB1), a novel AstV while species 8 (MAstV8; GII.A) includes HMOAstV-A and HAstV-VA2) and species 9 (MAstV9; GII.B) HMOAstVs -B and -C and HAstV-VA1). VA1 was first identified in an outbreak of diarrheal disease, while VA2 and VA3 were identified in a cohort of children with diarrheal disease in India. HMO-A, B, and C were simultaneously described in stools from Nigeria, Pakistan and Nepal.

The recent identification of novel HAstV highlights the necessity to analyze the prevalence of these viruses in order to recognize their actual impact in public health. Those viruses were found to be genetically related to animal viruses and, some of them were isolated from patients with more severe disease, such as encephalitis.

\section{Rotavirus and Astroviruses}

Like other gastroenteric viruses, rotavirus (RV) and human astrovirus (HAstV) ocurrence have been routinely reported in sewage and several environmental matrices worldwilde. Waterborne disease is of concern for RV since it is the most important viral agent causing infantile gastroenteritis with a burden in public health and significant environmental distribution. HAstV on the other hand, cause milder cases of gastroenteritis when compared to RV infections but are considered the second or third viral etiological agent of gastroenteritis worldwide. Both similarly effect children thus are considered here together.

\subsection{Epidemiology of the Disease and Pathogen(s)}

\subsection{Global Burden of Disease}

Worldwide, rotaviruses are the leading cause of acute gastroenteritis and dehydration in infants and young children up to 5 years old, accounting for about $28 \%$ of all gastroenteritis cases and being responsible in 2008 for approximately 453,000 RV-associated deaths of children worldwide (Tate et al., 2012; Walker et al., 2013). The reduction in mortality and severe gastroenteritis rates 
following the RV vaccine introduction in the last decade has been documented in many countries. However, despite the significant reduction, RV remains associated with approximately 215,000 (range 197,000-233,000 deaths/per year) deaths of children up to 5 years old annually (Tate et al., 2016). RV disease has a universal distribution, but with different epidemiological characteristics in different climatic regions. Temperate countries usually presents periods of gastroenteritis occurrence associated to RV within the winter-spring months. In the tropical areas, seasonality has not been as marked, manifesting itself by sporadic cases and/or outbreaks throughout the year (Levy et al., 2009; Patel et al., 2012). Based on its antigenicity and genetic characteristics, RV can be classified into nine species, designated RVA-RVI according to the International Committee on Taxonomy of Viruses (ICTV) (ICTV, 2018). RVA, RVB, RVC, and RVH are known to infect both humans and animals, while RVD, RVE, RVF and RVG have been found to infect exclusively animals (Matthjinssens et al., 2010; 2012). Epidemiologically, among all the serogroups, RVA is the most important for human infection in both developed and developing countries (Estes \& Greenberg, 2013). In regard to HAstV, the frequency of gastroenteritis ranges from 2 to $11 \%$ in developed and from $2 \%$ to $26 \%$ in developing countries(Chikhi-Brachet et al., 2002; Cunliffe et al., 2002; Dalton et al., 2002; Ratcliff et al., 2002). It is an important causative agent of infections that occurs in communities (about $27 \%$ of cases), with a lower rate of hospitalized children (1.6\% a 16\%) (Gaggero et al., 1998; Ratcliff et al., 2002; Walter \& Mitchell, 2003; Jakab et al., 2004).

\subsubsection{Global Distribution}

RVA has a worldwide distribution although the prevalence of strains oscillates according to geographical region. RVA strains are characterized by a binary classification system based on analysis of the VP7 and VP4 proteins: VP7 protein determines the G (glycoprotein) and the protein VP4 determines the P (protease sensitive) serotypes/genotypes of RVA. So far, there are $36 \mathrm{G}$ genotypes and $51 \mathrm{P}$ genotypes described in the literature (Rotavirus Classification Working Group, available in: https://rega.kuleuven.be/cev/viralmetagenomics/virusclassification/rcwg). Epidemiological studies of RVA infections have evidenced, at least, six G genotypes (G1-G4, G9 and more recently G12) and three P genotypes (P[4], $\mathrm{P}[8]$ and $\mathrm{P}[6])$ circulate globally generating a major impact on public health (Iturriza-Gómara et al., 2009; Bányai et al., 2012; Matthijnssens \& Van Ranst, 2012, Dóró et al., 2014). RVB has been detected in children, cattle, sheep, pigs, goats and mice besides being related to cases of diarrhea in adults in India (Chasey, et al., 1984; Snodgrass et al., 1984; Chinsangaram et al., 1994; Theil et al., 1995; Chang et al., 1997; Tsunemitsu et al., 1999; Sanekata et al., 2003; Barman et al., 2004; Estes \& Greenberg, 2013). RVC was first detected in pigs in 1980, and has been subsequently isolated in humans (Mwenda et al., 2003; Esona et al., 2008), ferrets, cattle, and dogs. RVC has also been associated with human outbreaks in Brazil, China, Finland, Japan, Sweden, and United Kingdom (Saif et al., 1980; Rodger et al., 1982; Torres-Medina, 1987;Caul et al., 1990;
Tsunemitsu et al., 1991; Maunula et al., 1992; Cox et al., 1998; Souza et al., 1998; Otto et al., 1999; Nilsson et al., 2000; Yang et al., 2004; Kuzuya et al., 2005; Lizuka et al., 2006; Kumazaki et al., 2015). HAstV are responsible for up to $20 \%$ of sporadic cases of nonbacterial acute gastroenteritis, with incidence rates ranging from $0.5 \%$ to $15 \%$ in outbreaks of acute gastroenteritis (De Benedicitis et al., 2011). These viruses present a mean incidence of $11 \%$ worldwide, being $7 \%$ and $23 \%$ in urban and rural areas, respectively (Bosch et al. 2014). Although HAstV are present in both developing and developed countries, higher incidences are observed in the low-income countries. Classic HAstV infections circulate throughout the year, however, a peak of detection has been observed in colder month of temperate regions and decrease drastically in the warmer months of the year. In tropical areas, high incidence of classic HAstV infections is likely to occur in the rainy season (Bosch et al., 2014).

\subsubsection{Symptomatology}

The clinical manifestations of RVA infections are not specific, thus laboratory confirmation is required for definitive diagnosis. RVA can cause symptomatic and asymptomatic infections in older children and adults; a common feature that may contribute to the rapid global spread of the virus (Anderson \& Weber, 2004; Anderson et al., 2015). The incubation period is approximately 2 days after infection, frequently including a watery acute diarrhea accompanied or not by fever, vomiting episodes and abdominal pain. Approximately one-third of the infected children may present fever greater than $102^{\circ} \mathrm{F}$ $\left(39^{\circ} \mathrm{C}\right)$. The disease is self-limiting and the gastrointestinal symptoms usually resolve in 3 to 7 days (Estes \& Greenberg, 2013; CDC, 2015). The loss of fluids and electrolytes due to vomiting and diarrhea can lead to severe dehydration, hospitalization, and death, especially in infants and underweight children (Wickelgren, 2000). Recently, few studies have reported the occurrence of HAstV in older children and adults (Pativada et al., 2012; Bosch et al., 2014), although mostly it is the young children, the elderly and immunocompromissed patients which form the high-risk group for the symptomatic disease. The majority of the symptomatic cases of HAstV infection are self-limited lasting 2 to 3 days associated with watery diarrhea, vomiting, fever, anorexia and abdominal pain. Asymptomatic infections have been also described in children and adults (Mendez-Toss et al., 2004). Although majority of the patients infected by HAstV recover without any intervention, some exhibit dehydration due to poor nutritional status and mixed infections (Mendez \& Arias, 2013).

\subsection{Taxonomic Classification of the Agent (s)}

Rotaviruses belong to the genus Rotavirus, within the family Reoviridae. It can be classified by the analysis of the outer capsid proteins VP7 and VP4 that provides the RVA binary system of classification with $G$ and $P$ serotypes/genotypes, respectively. Serotypes are based on immunologic detection methods (MAb-ELISA and crossneutralization assays) while genotypes are detected by 
molecular techniques, such as reverse transcriptionpolymerase chain reaction (RT-PCR) and nucleotide sequencing. Seeking a better understanding on the RVA strains diversity, a new classification system was proposed by the Rotavirus Classification Working Group, based on nucleotide sequence identity with cutoff percentages for each one of the 11 dsRNAs segments (Matthijnssens et al., 2011). The new RVA classification assigns a genotype to each viral protein as follows: Gx-P[x]-Ix-Rx-Cx-Mx-Ax-Nx-TxEx-Hx that is VP7-VP4-VP6-VP1-VP2-VP3-NSP1-NSP2NSP3-NSP4-NSP5/6. To date, 32G, 47P, 24I, 18R, 17C, $17 \mathrm{M}, 28 \mathrm{~A}, 18 \mathrm{~N}, 19 \mathrm{~T}, 24 \mathrm{E}$ and $19 \mathrm{H}$ genotypes have been identified from humans and/or animals (Rotavirus Classification Working Group, available in: https://rega.kuleuven.be/cev/viralmetagenomics/virusclassification/rcwg). HAstV are non-enveloped, singlestranded, positive-sense, polyadenylated RNA viruses that belong to the Astroviridae family and were initially divided into eight genotypes. In general, HAstV-1 is the most common in children, but the predominant genotype can vary according to geographic area, as well as the environmental dissemination. Originally, astroviruses were classified into genera (Mamastrovirus and Avastrovirus) and species based only on the host of origin. However, since 2011, the classification is based on the full-length amino acid sequence of the ORF2 capsid region, the most variable region of the genome (Bosch et al., 2014). This new classification divides the Mamastrovirus genus into 19 species comprising viruses from human and animal origin. Mamastrovirus species 1 (MAstV1) includes HAstV 1 to 8 (classic HAstV) and species 6 (MAstV6) MLB1 (AstV-MLB1), a novel HAstV, while VA/HMO HAstV are grouped within the MAstV-8 and 9. The recent identification of novel HAstV highlights the necessity to analyze the prevalence of these viruses in order to recognize their actual impact in public health. These novel viruses were found to be genetically related to animal viruses and, some of them were isolated from patients with more severe diseases, such as encephalitis (Bosch et al., 2014).

\subsubsection{Physical description of the agent}

RVA was first described by electron micrography by Bishop et al. (1973). This virus was subsequently called "rotavirus" because of its similarity to a wheel (rotais Latin for wheel). RVA have triple-layered protein capsid, $100 \mathrm{~nm}$ in diameter (from one spike to another), icosahedral symmetry, are non-enveloped particles (resistant to lipid solvents) and their capsid contains all enzymes required for mRNA production. The genome is composed by 11 segments double-stranded (ds) segmented ribonucleic acid (dsRNA), where each segment encodes one viral protein, except for the segment 11 which encodes 2, totaling 12 proteins: 6 structural (VP1-VP4, VP6 and VP7) and 6 nonstructural (NSP1-NSP6), which support various virus functions, including genome replication, particle assembly and regulation of host innate responses (Estes \& Greenberg, 2013). The innermost capsid of the RVA is composed by the core shell protein VP2 (McClain et al., 2010). Attached to the interior side of the VP2 are the proteins VP1 (RNA- dependent RNA polymerase) and VP3 (RNA capping enzyme)., associated to the dsRNA genome forming the core, which is surrounded by VP6, the unique component of the intermediate protein layer and the most abundant viral protein, accounting for about $51 \%$ of the virion. The outer protein layer of the virion consists of the VP7 glycoprotein. Projecting outward from the VP7 layer are 60 spikes of the protease-activated attachment protein VP4 (Estes \& Greenberg, 2013). HAstV was initially visualized by electron microscopy (EM) analysis of stool samples from children presenting acute gastroenteritis (Madeley \& Cosgrove, 1975). The surface of these viruses in the EM analysis presented a roughly star-shaped configuration, and it was for this reason that this group of viruses was called "astrovirus" ("astron" means star in Greek). The viral particle has an icosahedral symmetry of 28-30 $\mathrm{nm}$ in diameter with spikes from the surface similar to a star-like form. The infectious particles are constituted by three proteins in the range of 32-34, 27-29 and 25-26 kd, depending on the virus strain. The genome is composed of a single strand RNA of positive polarity of approximately $7 \mathrm{~kb}$ excluding the poly(A) tail at the $3^{\prime}$ end. A VPg protein is covalently linked to the $5^{\prime}$ end of the genome. This genome includes an untranslated region (UTR) at both 3 'and 5 'ends of the RNA molecule and three open reading frames (ORF) (Mendez \& Arias, 2013).

\subsubsection{New variants}

RVA are ubiquitous, interspecies-transmitted, and accumulation of point mutations, recombination and reassortment are responsible for the huge genetic heterogeneity of these viruses. Consequently, these characteristics associated with the spreading of different RVA genotypes and genetic variants in distinct geographical regions, as well as over the seasons, may be associated with the emergence of severe gastroenteritis globally (Carvalho-Costa et al., 2011; WHO, 2013). Astroviridae family constitutes a genetically diverse group of emerging viruses with divergent AstV infecting a single host species. In the last decades, a downward trend in the incidence of classic HAstV was observed, as demonstrated in France and Japan, raising the possibility of replacement of these classic HAstV infections by the novel HAstV MLB and VA/HMO infections (Bosch et al. 2014). Regardless of these novel HAstVs (MLB and VA/HMO) have been detected in stool samples of persons presenting with acute gastroenteritis. They have also been identified in serum of a febrile child (MLB2) and brain tissue of a child with encephalitis (VA1) (Quan et al., 2010; Holtz et al., 2011).

\subsection{Transmission}

\subsubsection{Routes of transmission}

RVA and HAstV are transmitted by the fecal-oral route and quickly spread through person-to-person contact (Estes \& Greenberg, 2013), airborne droplets and fomites (Estes \& Greenberg, 2013). Transmission is also observed by ingestion of contaminated water and food and cases of RVA- and HAstV-associated waterborne disease have been reported (Gallay et al., 2006; Martinelli et al., 2007; Moreno et al., 2009; Koroglu et al., 2011, Villena et al., 2013; Kittigul et al., 2014; Mellou et al., 2014; Quiroz- 
Santiago et al., 2014; El-Senousy et al., 2015).

\subsubsection{Reservoirs}

There is a wide diversity of animal species infected with RV and AstV, which have great genetic diversity (Wolfaardt et al., 2011). Thus, different animal species might act as reservoir and eventually infect humans through a crossspecies transmission and subsequent adaptation of the viruses to the new host (De Benedectis et al. 2011, Estes \& Greenberg, 2013). In addition to infecting humans, RVA has been detected in different species including farm animals (cows, pigs, and sheep), wild animals (llamas, giraffes), nonhuman primates (macaques), domestic pets (dogs, cats), rodents, and birds (Martella et al., 2010). RVA detected in animals can infect humans, either by direct transmission of the virus or by sharing one or several genes to reassortants with essentially human genetic background (Müller and Johne, 2007). The identification of novel HAstV that are genetically related to AstV isolated in rats, sheep and minks suggests that wild mammals might act as reservoir for human infections. The identification of a recombinant event that may have occurred between a human (HAstV-4) and a California sea lion (CslAstV-2) astroviruses support this hypothesis (Rivera et al. 2010). High genetic diversity has been found in AstV infecting bats and pigs suggesting that a human infection by an animal AstV is possible (Mendez \& Arias, 2013). Similar to RVA, AstV strains have been identified in feces of several mammals like cats, cattle, deer, dogs, mice, rats, pigs, sheep, mink, bats, cheetahs, rabbits, sea lions and dolphins; in addition to avian species like turkeys, chikens, ducks, pigeons, guinea fowl and also in other wild aquatic birds (Bosh et al., 2014).

\subsubsection{Incubation period}

The incubation period for RVA-associated diarrhea can range from $24 \mathrm{~h}$ to $48 \mathrm{~h}$ (Estes \& Greenberg, 2013). For HAstV the incubation period observed in studies with adult volunteers was established as 3 to 4 days with the highest viral excretion at day 6 , which is proportional to the severity of the illness (Mendez \& Arias, 2013).

\subsubsection{Period of communicability}

Two days before the onset of diarrhea and for up to 10 days after the symptoms a RVA infected person can shed concentrations of $10^{10}$ to $10^{12}$ of virus per gram of faeces in stools and vomitus (Bishop et al., 1996; Ramani et al., 2010; Estes \& Greenberg, 2013). For HAstV viral load in fecal samples from children hospitalized with acute gastroenteritis ranged from $7.6 \times 10^{2}$ to $3.6 \times 10^{15}$ genomic copies (GC) per gram of feces (Zhang et al. 2006). The duration of HAstV shedding after the onset of signs of acute gastroenteritis in outbreaks ranged from one to 22 days (Akihara et al. 2005). HAstV viral shedding in stools from infants presenting severe primary combined immunodeficiency can persist for almost 9 months (Wunderli et al. 2011).

\subsubsection{Population susceptibility}

RVA infect nearly every child by the age of 3-5 years, regardless the geographical area (Velazquez, 2009; PATH, 2014). In developing countries, the average age at the primary RVA infection ranges from 6 to 9 months $(80 \%$ occur among infants whereas in developed countries the first episode may occasionally be postponed until the age of 2-5 years, though the majority still occurs in childhood (65\% occur among infants WHO, 2013). RVA infections are usually more severe in children under three years old, and the clinical manifestations can be more severe in the first infection than in the reinfections (CDC, 2014). HAstV causes gastroenteritis mainly in children, usually less than 2 years, although immunocompromised persons and the elderly are also a group at high risk (De Benedictis et al. 2011). In highly immunocompromised children, HAstV classic infections can spread systemically and cause serious or fatal infections (Wunderli et al. 2011). HAstV associated diarrhea cases have been reported in healthy adults (Belliot et al 1997; Pager and Steele, 2002), asymptomatic children (Mendez-Toss et al., 2004) and in symptomatic cases (Kiulia et al., 2007).

\subsection{Population and Individual Control Measures}

RVA affect children of all social classes, indicating that, unlike other enteric pathogens of fecal-oral transmission, improvements in basic sanitation and hygiene procedures seems to be not sufficient to control the virus infection (Barreto et al., 2006). RVA is persistent in environment and extremely infectious (ID50 is $\sim 6$ viral units) (Julian, 2016). Therefore, the most effective approach to control RVA infections is by vaccination (Estes \& Greenberg, 2013). In gastroenteritis outbreaks, the interruption of transmission is the leading strategy to control, especially in hospitals and nurseries. The elimination of common sources of infection, as well as the interruption of transmission by person-toperson contact are effective measures for controlling infections. It is essential to emphasize the importance of hand hygiene; with soap and water before and after contact with individuals or with objects, which may be contaminated as well as disinfecting contaminated surfaces (Wilhelmi et al., 2003). The treatment of RVA-associated diarrhea is based on restoring the loss of fluids and electrolytes. For children rehydration, it can be used the formula recommended by WHO or other commercial available. These formulas have been shown to be effective for children with moderate dehydration. In cases of severe diarrhea, the use of intravenous fluids is recommended, or if the child has difficulty in swallowing due to the intensity of the vomiting. Nutritional therapy and medical assistance are extremely important, helping to reduce the morbidity and mortality caused by the RVA (Bernstein, 2009). There are no antiviral drugs available for the treatment of RVA infections; however, studies demonstrate the antiviral activity of some drugs against these viruses (Rossignol et al., 2006; Teran et al., 2009; La Frazia et al., 2013; Shen et al., 2013). Nitazoxanide, an agent used in the treatment of helminth and protozoa, is being tested for possible therapeutic use in case of gastroenteritis caused by RVA in children (Dennehy, 2013). Doses of $15 \mathrm{mg} / \mathrm{kg} /$ day twice a 
day for three days significantly reduced the duration of diarrhea and hospitalization in children with RVAassociated diarrhea. Despite HAstV infections being the cause of mild and self-limiting gastroenteritis, severe cases of the diseases including deaths have been reported (Cubitt et al., 1999; Wunderli et al., 2011). Patients with severe gastroenteritis and dehydration are treated with oral or intravenous fluid replacement (Bosch et al., 2014).

\subsubsection{Vaccines}

\subsubsection{Types of vaccines}

Currently, there are two RVA live vaccines available worldwide. Rotarix ${ }^{\circledR}$ (RV1) (GlaxoSmithKline, Rixensart, Belgium), an attenuated monovalent vaccine, derived from a human G1P[8] strain, is administered orally to infants at 2 and 4 months of age (O'Ryan, 2007). Rotateq ${ }^{\circledR}$ (RV5) (Merck and Co, Whitehouse Station, NJ, USA; Sanofi Pasteur MSD, Lyon, France), is a pentavalent vaccine comprising five human-bovine reassortant strains: four expressing human G1, G2, G3, G4 and bovine P[5] and one reassortant expresses P[8] (human) and G6 (bovine) administered orally to infants at 2, 4 and 6 months of age (Heaton \& Ciarlet, 2007). Furthermore, there are others locally available vaccines in Asia, such as Rotavac (Bharat Biotech International, Hyderabad, India), a human-bovine reassortant vaccine containing G9P[11] genotype in India and vaccines in China and Thailand. To date no vaccine has been developed for HAstV, although production of virus-like particles in different expression systems has been described (Dalton et al., 2003; Caballero et al., 2004).

\subsubsection{Global vaccine coverage rate}

Both RV1 and RV5 are approved and recommended by the WHO. They were initially approved for use in Europe and the Americas based on efficacy data from these regions in 2006. Subsequently, after evidence of efficacy in Asia and Africa, WHO has recommended their introduction into every country's national immunization program, particularly in countries where diarrheal disease was a major health problem (WHO, 2009). ). Until May $1^{\text {st }}, 2016$, 81 countries have introduced the RVA vaccines in their national immunization programs (available in: http://sites.path.org/rotavirusvaccine/country-introductionmaps-and-spreadsheet). Other countries, such as Canada, the Philippines, and Thailand, have introduced this vaccine in pilot or regional settings. The RVA vaccines are also available in more than 100 countries through the private market. Both vaccines (RV1 and RV5) significantly reduced physician visits for diarrhea and RVA-related hospitalization since their efficacy has been demonstrated against the most predominant RVA genotypes detected worldwide (Ruizpalacios et al., 2006; Vesikari et al., 2006; Cortese et al., 2013; Rha et al., 2014). Herd immunity has also been suggested by studies from different countries that have introduced universal RVA vaccination (Paulke-Korinek et al., 2011; Rha et al., 2014; da Silva et al., 2015). Postmarket surveillance studies indicated a slight risk of intussusception after vaccination with RV1 and RV5. Studies conducted in Brazil and Mexico showed a relative risk between 1.9 and 2.6 for 1-7 days after the second dose of RV1 (Patel et al., 2011). Rha et al. (2014) summarized the data available on the safety of RVA vaccines concerning intussusception and described a risk of intussusception between 0.7 and 7 in 100,000 vaccinated children for RV1 and 2.0 to 7.7 per 100,000 vaccinated children for RV5. Otherwise, the data on cost-benefit shows that vaccination benefits compensate the low risk of intussusception occurrence after the vaccination with RV1 or RV5.

\subsubsection{Shedding with live vaccines}

Most pre licensure RV1 studies using ELISA to detect shedding found that approximately $50 \%$ of infants shed vaccine strain after the first dose (usual range 35-80\%, depending on the dose and study parameters) (Vesikari et al., 2004; Dennehy et al., 2005; Phua et al., 2005; Salinas et al., 2005; Ruiz-Palacios et al., 2007). The shedding of the RV1 in faeces is more commonly detected after the first dose rather than after the second dose, with some studies observing that its occurrence after the second dose are related to patients who did not develop an antibody response after the first dose (Vesikari et al., 2004; Phua et al., 2005; Ward et al., 2006). In several studies, RV5 shedding has occurred in $0-13 \%$ of vaccine recipients after first dose, $0-7 \%$ after the second dose, and $0-0.4 \%$ after the third dose (Clark et al., 2003; 2004; Vesikari et al., 2006; Gouvea et al., 2007; Block et al., 2007). The package insert for the vaccine summarizes data from the major RV5 trial (Vesikari et al., 2006), which evaluated RV5 shedding in a group of patients 4-6 days after each dose and among all patients with a positive rotavirus sample at any time (Merck, 2007). Transmission was not investigated; shedding after vaccine doses occurred between days 1 and 15 and occurred in 32 (9\%) of 360 recipients after the first, none $(0 \%)$ of 249 recipients after the second, and one $(0.3 \%)$ of 385 recipients after third dose (Merck, 2007).

\subsubsection{Future aspects}

The genetic diversity of the RVA, as well as some intrinsic characteristics of these viruses, such as the temporal fluctuations of genotypes and the interspecies barrier broken to generate new combinations or novel strains will always require an active laboratory surveillance to monitor and evaluate the circulating genotypes. In this context, it is essential to maintain active surveillance studies in order to predict the possible variants that might circulate in a country, as well as to assess the effects and the impact of the RV vaccination to aid in future RVA vaccine design and development (Fumian et al., 2011; Linhares et al., 2011, da Silva et al., 2013; 2017). In attempt to evaluate the impact of vaccination programs on viral strains circulating after RVA introduction, environmental surveillance studies were conducted in Brazil and Nicaragua (Bucardo et al., 2011, Fumian et al. 2011). Through the analysis of sewage samples from an urban area in Rio de Janeiro (Brazil), different Brazilian studies demonstrated the genotypes fluctuation after the introduction of RV1 vaccine in the National Immunization Program in 2006 in the country (Ferreira et al., 2009; Prado et al., 2011, Fumian et al., 2011). In Nicaragua, the impact of the pentavalent RV5 vaccine was evaluated by 
investigating RV dissemination in urban and hospital wastewater of the city, demonstrating that RVA declined in the community after two years of the introduction of vaccination program. (Bucardo et al., 2011).

\subsubsection{Hygiene measures}

The most effective way to prevent RVA and HAstV infections is based essentially through the interruption of the transmission. This is essential for the control of those infections in close setting like hospitals, daycare centers and families where the person-to-person transmission is likely to occur (Mendez \& Arias, 2013). It is of vital importance hands hygiene to be emphasized, where thorough hand washing with soap and water before and after contact with the patient or with objects that may be contaminated (Wilhelmi et al, 2003). Hands can donate or receive virus during occasional contact surfaces animate and inanimate, In this case proper and regular decontamination of hands on the part of health professionals is essential to prevent and control the spread of viruses and other pathogens (Ansari et al., 1988). Disinfection of contaminated fomites can be achieved with $90 \%$ alcohol and in the case of drinking water, treatment with $1 \mathrm{mg}$ of free chlorine per liter is effective (Kurtz et al. 1980; Abad et al. 1997).

\section{Environmental Occurrence and Persistence}

\subsection{Detection Methods}

Over the last 30 years (since 1980) RVA have been identified in sewage or drinking water using several virus detection techniques such as; enzyme-linked immunosorbent assay and electron microscopy or immunofluoresce after cultivation in African Green Monkey kidney cells(MA 104) (Steinmann et al., 1982; Deetz et al., 1984; Hejkal et al., 1984; Agbalika et al., 1985). Multiplex nested polymerase chain reaction preceded by reverse transcription (nRT-PCR), using consensus and specific primers for amplifying the genes encoding the VP4 and VP7 proteins (Gouvea et al, 1990; Gentsch et al, 1992; Das et al, 1994), has been successfully used to detect RVA from environmental samples thereby, determining the predominant genotypes in different geographical areas (Kamel et al., 2010, Kiulia et al., 2010, Rodriguez-Diaz et al., 2009, El-Senousy et al., 2015). A RT-PCR VP6 protocol has also been used as a screening tool to increase the range of viral detection (Iturriza-Gomara et al, 2002; Ferreira et al.,2009) (protocols available in: http://apps.who.int/iris/bitstream/10665/70122/1/WHO_IVB 08.17_eng.pdf). A quantitative reverse transcription PCR (RT-qPCR) using the NSP3 gene protocol (Zeng et al., 2008) as a target has been also used to assess viral concentration of RVA in environmental samples (Fumian et al., 2011; 2013; Vieira et al., 2012; Prado et al., 2012; Victoria et al., 2014). The segment encoding the NSP3 protein is described to be more conserved than the VP6 enconding gene (Pang et al., 2004) and the NSP3 RT-qPCR protocol detection range from 3 to $3 \times 10^{8}$ genomic copies per reaction. To overcome some limitations associated with direct RT-qPCR method, an integrated cell culture and quantitative RT-qPCR (ICC-RT-qPCR) method for detecting and quantifying infectious RVA has also been described ( $\mathrm{Li}$ et al., 2009). The detection of HAstV initially was only performed by detecting virus particles by EM, a laborious, time-consuming and limited technique, mainly because only $10 \%$ of the particles displays the typical star-like structure (Cubitt et al., 1999). Herrmann et al. (1990) have described the detection of HAstV by enzyme-linked immunosorbent assay (ELISA). Nowadays, two commercial ELISA tests are used for screening HAstV infections in stool samples. Based on the sensitivities of $36 \%-38 \%$ and specificities of 88\%-96\% when compared to the RT-PCR, these tests are considered useful for a preliminary screening for HAstV outbreaks (De Bruin et al., 2006). HAstV grows in vitro with the use of CaCo-2 cell combined with a pretreatment with trypsin. Virus isolation remains the gold standard method for classic HAstV detection from clinical and environmental samples (Willcocks et al., 1994; Brinker et al., 2000; Bosch et al., 2014.). A method based on infection of CaCo-2 cultured cell monolayers (CC) and reverse transcriptionPCR (CC-RT-PCR) was developed for the specific detection of infectious astrovirus (Abad et al., 1997) and has been used to demonstrate HAstV infection (Chapron et al., 2000). Due to the great genetic variability between the species at the Astroviridae family, different sets of primers have been designed to detect different species of AstV. For classic HAstV the set of primers Mon269/Mon270, targeting the conserved 5' end of ORF2, is widely used for detecting and sequencing of the generated amplicon (Noel et al., 1995). A consensus set of primers designed for a conserved region located in the ORF-1b can detect both classic and novel HAstV strains (Finkbeiner et al., 2009a, 2009b). An improvement to the conventional RT-PCR is the quantitative RT-PCR (RT-qPCR) for HAstV, which provides high sensitivity and reduction of cross contamination between samples (Le Cann et al., 2004; Dai et al., 2010). More recently, metagenome analysis has been used for identifying a viral pathogen diversity including gastroenteric viruses from several environmental matrices (Paul et al., 2011; Bibby \& Peccia, 2013).

\subsection{Data on Occurrence in the Environment}

Outbreaks associated with RVA, resulting from contamination of waters by sewage, have been reported in several countries such as Albania, Belgium, Canada, China, Finland, France, Greece, Italy, Russia, Sweden, Turkey, and United States of America (USA) (Lycke et al., 1978; Hopkins et al., 1984; Hung et al., 1984; Solodovnikov et al., 1989; Ansari et al., 1991; Kukkula et al., 1997; Villena et al., 2003; Borchardt et al., 2004; Divizia et al., 2004; Gallay et al., 2006; Martinelli et al., 2007; Rasanen et al., 2010; Koroglu et al., 2011; Mellou et al., 2014; Braeye et al., 2015). Data on the occurrence of RVA in environmental samples has been generated mostly by studies carried out in developing countries, where RVA still have significant morbidity when compared to developed ones. The high occurence of RVA observed in urban polluted ponds or streams in cities with high population density are related to several factors, including the precariousness of housing and/or the lack of sanitation in some geographic areas (Mehnert et al., 1993, Mehnert \& Stewien, 1993; Gajardo et 
al., 1995; Lodder et al., 1999; Hafliger et al., 2000; Kittigul et al., 2001; Abbaszadegan et al., 2003; John \& Rose, 2005; Pusch et al., 2005; Podewils et al., 2007; Espinosa et al., 2008; Miagostovich et al., 2008; Ferreira et al., 2009; He et al., 2009; Rodriguez-diaz et al., 2009; Rutjes et al., 2009; Wong et al., 2009; Victoria et al., 2010; Fumian et al., 2010; 2011, Prado et al., 2011, Vieira et al., 2012).

\subsubsection{Sewage}

Detection of RVA in sewage samples has been described since 1980s, when the classical virology methods were used in an attempt to detect and enumerate those viruses (Steinmann et al., 1982; Deetz et al., 1984, Hejkal et al., 1984; Agbalika et al., 1985). In 1993, a study on raw sewage in the city of São Paulo (Brazil) reported 6 of 29 sewage samples $(20.6 \%)$ as positive with levels ranging from liter (geometric mean was $2.2 \mathrm{FFU} / \mathrm{liter}$ ). RVA was counted by indirect immunofluorescence and direct immunoperoxidase in this study. A higher rate of positivity for RVA during autumn and winter months than those collected in spring and summer was observed (Mehnert \& Stewien, 1993). In the following years, others studies reporting RVA in raw or treated sewage were also described (Dubois et al., 1997). From the year 2000 molecular studies have reported data not only on the occurrence but also on genotype diversity and viral concentration of RVA worldwide (Table 1). In Egypt, studies also reported the presence of bovine RVA (Kamel et al., $2010)$ and RVC ranging from non-detect to $12.5 \%(3 / 24)$ at different stages of treatment at a wastewater treatment plant in the country (El-Senousy et al., 2015). Using data on excretion of RVA in feces, occurrence in raw and treated sewage, a global map showing the emission of RVA from sewage to surface waters estimated that gobally a total of $2.0 \times 10^{18} \mathrm{RVA}$ viral particles/year are emitted into surface waters of which $87 \%$ are produced by the urban population (Kiulia et al., 2015). 
Table 1. Natural occurrence of Rotavirus in raw sewage

\begin{tabular}{|c|c|c|c|c|}
\hline Area & Genotypes & $\begin{array}{l}\text { Percent } \\
\text { Positive }\end{array}$ & $\begin{array}{c}\text { Concentrations } \\
\text { Averages } \\
\text { (ranges), GC/L }\end{array}$ & Reference \\
\hline $\begin{array}{l}\text { Argenúina } \\
\text { (Cordoba) }\end{array}$ & G1, G2, G3, G4, G8, G9 & $\begin{array}{l}100.0 \% \\
(52 / 52)\end{array}$ & NR & Barril et al., 2010 \\
\hline $\begin{array}{l}\text { Argentina } \\
\text { (Cordoba) }\end{array}$ & $\begin{array}{l}\text { G1, G2, G3, G4, G8, } \\
\text { G9,P[4], P[8] }\end{array}$ & $\begin{array}{l}91.4 \% \\
(32 / 35)\end{array}$ & $2.2 \mathrm{E}+02$ to $4.1 \mathrm{E}+05$ & Barril et al., 2015 \\
\hline $\begin{array}{l}\text { Brazil } \\
\text { (Porto Alegre) }\end{array}$ & NR & $\begin{array}{l}28.6 \% \\
(2 / 7)\end{array}$ & NR & Vecchia et al., 2012 \\
\hline $\begin{array}{l}\text { Brazil } \\
\text { (Rio de Janeiro) }\end{array}$ & G3, G4, G9 e P[6] e P[8] & $\begin{array}{l}45.8 \% \\
(11 / 24)\end{array}$ & NR & Ferreira et al.,2009 \\
\hline $\begin{array}{l}\text { Brazil } \\
\text { (Rio de Janeiro) }\end{array}$ & SGII a & $\begin{array}{l}70.6 \% \\
(24 / 34)\end{array}$ & $5.9 \mathrm{E}+03$ to $2.9 \mathrm{E}+08$ & Prado et al., 2011 \\
\hline $\begin{array}{l}\text { Brazil } \\
\text { (Rio de Janeiro) }\end{array}$ & G2, P[4], P[6] & $\begin{array}{c}100 \% \\
(24 / 24)\end{array}$ & $2.40 \mathrm{E}+05$ & Fumian et al., 2011 \\
\hline $\begin{array}{l}\text { China } \\
\text { (Beijing) }\end{array}$ & NR & $\begin{array}{l}44.4 \% \\
(16 / 36)\end{array}$ & $3.12 \mathrm{E}+03$ & He et al., 2009 \\
\hline $\begin{array}{l}\text { Egypt } \\
\text { (Cairo) }\end{array}$ & G1,G3, G4, G9, P[4], P[6], P[8] & $\begin{array}{l}87.5 \% \\
(30 / 35)\end{array}$ & NR & Villena et al. 2003, \\
\hline $\begin{array}{l}\text { Egypt } \\
\text { (Cairo) }\end{array}$ & G1, G2, G9, G12, P[4], P[8] & $\begin{array}{l}8.3 \% \\
(6 / 72)\end{array}$ & NR & Kamel et al., 2010 \\
\hline $\begin{array}{l}\text { Italy } \\
\text { (Otranto) }\end{array}$ & G1, G2 & $\begin{array}{l}37.5 \% \\
(6 / 16)\end{array}$ & NR & Grassi et al., 2010 \\
\hline $\begin{array}{l}\text { Italy } \\
\text { (Naples, Bari, Palermo } \\
\text { and Sassari) }\end{array}$ & $\begin{array}{l}\text { G1, G2, G3, G4, G6, G9, G26, P[4], } \\
\text { P[6], P[8], P[9], P[14], P[19] }\end{array}$ & $\begin{array}{c}60.4 \% \\
(172 / 285)\end{array}$ & NR & Ruggeri et al., 2015 \\
\hline $\begin{array}{l}\text { Kenya } \\
\text { (Karen) }\end{array}$ & $\begin{array}{c}\text { G1, G4, G5, G8, G9, G10, G11, } \\
\text { G12, P[4], P[8] }\end{array}$ & $\begin{array}{l}69.2 \% \\
(9 / 13)\end{array}$ & NR & Kiuilia et al.,2010 \\
\hline $\begin{array}{l}\text { Spain } \\
\text { (Barcelona) }\end{array}$ & $\begin{array}{l}\text { G1,G2, G3, G5, G9, } \\
P[4], P[6], P[8], P[9]\end{array}$ & $\begin{array}{c}66.9 \% \\
(239 / 357)\end{array}$ & NR & Villena et al., 2013 \\
\hline $\begin{array}{l}\text { Tunisia } \\
\text { (Monastir region) }\end{array}$ & G3, G4, P[4], P[8] & $\begin{array}{c}42.4 \% \\
(53 / 125)\end{array}$ & NR & Sdiri-Loulizi et al., 2010 \\
\hline $\begin{array}{l}\text { Uruguay } \\
\text { (Melo, Treinta y Tres, } \\
\text { Bella Unión, Salto, } \\
\text { Paysandú and Fray } \\
\text { Bentos) }\end{array}$ & $\begin{array}{l}\text { G1,G2, G3, G12, } \\
P[3], P[4], P[8]\end{array}$ & $\begin{array}{c}52.6 \% \\
(61 / 116)\end{array}$ & NR & Tort et al., 2015 \\
\hline $\begin{array}{l}\text { USA } \\
\text { (Arizona) }\end{array}$ & NR & $\begin{array}{l}58.3 \% \\
(14 / 24)\end{array}$ & $2.8 \mathrm{E}+06$ & Kitajima et al., 2014 \\
\hline $\begin{array}{l}\text { Venezuela } \\
\text { (Caracas) }\end{array}$ & G1, G9, P[4], P[8] & $\begin{array}{l}66.7 \% \\
(8 / 12)\end{array}$ & NR & Rodriguez-Diaz et al., 2009 \\
\hline \multicolumn{5}{|c|}{${ }^{\text {a }}$ Serogroup II (Group A rotavirus classification based on VP6 analysis) } \\
\hline NR - Not Reported & & & & \\
\hline
\end{tabular}

HAstV have been detected at different rates in raw or treated sewage ranging from 29 to $100 \%$ in different countries (Table 2). In raw sewage, the concentration of HAstV ranged from $10^{2}$ to $10^{7} \mathrm{GC} / \mathrm{L}$ (Aw et al., 2010; Fumian et al., 2013). The concentration in secondary effluent (sewage treated mainly by activated sludge) varied from $10^{2}$ to $10^{6} \mathrm{GC} / \mathrm{L}$, although some reports observed no HAstV in effluents samples (Fumian et al., 2013; Prevost et al., 
2015). Similar to the molecular epidemiology observed in clinical samples, HAstV-1 is the most prevalent in sewage samples although the other genotypes have also been observed. In surveillance studies with sewage samples for more than one year, peaks in HAstV detection have been observed in winter months (Aw et al., 2010; $\mathrm{Ng}$ et al., 2012; Victoria et al., 2014; Zhou et al., 2014, Prevost et al., 2015).
Recently, the emergence of MLB and VA HAstV genotypes have been also observed in sewage samples in Japan and Uruguay (Hata et al., 2015; Lizasoain et al., 2015). Sewage surveillance conducted in sewage samples from Uruguay also detected canine astrovirus clustering with strains detected previously in Italy (2008) and Brazil (2012) (Lizasoain et al., 2015b).

Table 2. Natural occurrence of Astrovirus in raw sewage

\begin{tabular}{|c|c|c|c|c|c|}
\hline Area & $\begin{array}{l}\text { Study } \\
\text { Period }\end{array}$ & Genotypes & $\begin{array}{l}\text { Percent } \\
\text { Positive }\end{array}$ & $\begin{array}{c}\text { Concentrations } \\
\text { Averages (ranges), GC/L }\end{array}$ & Reference \\
\hline $\begin{array}{l}\text { Brazil } \\
\text { (Rio de Janeiro) }\end{array}$ & $\begin{array}{l}2009- \\
2010\end{array}$ & HAstV -1 & $\begin{array}{l}29.0 \% \\
(7 / 24)\end{array}$ & $1.8 \mathrm{E}+03$ & Fumian et al., 2013 \\
\hline $\begin{array}{l}\text { China (Jinan } \\
\text { Linyi) }\end{array}$ & 2013 & HAstV $(1,2,4,5)$ & $\begin{array}{l}39.0 \% \\
(9 / 23)\end{array}$ & NR & Zhou et al., 2014 \\
\hline France (Paris) & 2013-2014 & HAstV $(1,2,5,6)$ & $\begin{array}{c}84.0 \% \\
(84 / 100)\end{array}$ & $1.0 \mathrm{E}+03$ & Prevost et al., 2015 \\
\hline Japan & 2007-2008 & $\begin{array}{l}\text { HAstV }(1,2,4 / 8,5) \\
\text { VA1, VA2, MLB2 }\end{array}$ & $\begin{array}{l}100.0 \% \\
(6 / 6)\end{array}$ & $1.9 \mathrm{E}+04$ to $7.5 \mathrm{E}+05$ & Hata et al., 2015 \\
\hline Singapore & 2007 & HAstV $(1,2,8)$ & $\begin{array}{l}100.0 \% \\
(18 / 18)\end{array}$ & $3.7 \mathrm{E}+07$ & Aw et al., 2010 \\
\hline $\begin{array}{l}\text { Uruguay } \\
\text { (Bella Union, } \\
\text { Frey Bentos, } \\
\text { Paysandu, } \\
\text { Salto) }\end{array}$ & 2011-2012 & $\mathrm{NR}^{\mathrm{a}}$ & $\begin{array}{r}45.0 \% \\
(43 / 96)\end{array}$ & $3.2 \mathrm{E}+03$ to $4.3 \mathrm{E}+07$ & Victoria et al., 2014 \\
\hline
\end{tabular}

\subsubsection{Sludge}

In Brazil, RVA was detected in $33 \%$ of sewage sludge (Schilindwein et al., 2010) as well as in $45 \%$ of treated sludge after mesophilic anaerobic digestion (Prado et al., 2013). HAstV was detected in high frequency (94\%) in sludge biosolids from the United States by using beef extract elution and organic flocculation for viral concentration followed by integrated cell culture-reverse transcriptase-polymerase chain reaction coupled with nested PCR (Chapron et al., 2000).

\subsubsection{Surface waters}

RVA and HAstV occurence have been demonstrated in surface waters in several countries, mainly from rivers, streams and lake water samples (Tables 3,4). RVA detection (8.9 to 100\%) and/or genetic diversity were described by differrent countries, reporting RVA concentrations ranging from $3.0 \times 10^{1}$ to $2.5 \times 10^{7} \mathrm{GC} / \mathrm{L}$. It is important to note that seasonality may have affected these results because of factors like excretion and climate variability, which influences flows in the rivers. Under different hydrological scenarios of Rio Negro in Brazil, as example, RVA were more commonly detected during the flood season and difference in viral concentrations during the dry and flooding was statistically significant (pVieira et al., 2016). The frequency in detection of HAstV varies widely ranging from $2.9 \%$ in rivers from France to $67 \%$ in streams from Slovenia (Hot et al., 2003; Steyer et al., 2011). As observed for other enteric viruses, the presence of HAstV showed no correlation with the presence of bacterial indicators (Espinosa et al., 2009; Liang et al., 2015). The seasonality of HAstV detection in surface waters is controversial. Studies conducted in Germany and Mexico have not found any association between HAstV detection and the season of sampling collection (Rohayem et al. (2006) and Espinosa et al. (2009), nevertheless, a peak of HAstV detection in autumn and winter was observed in Slovenia (Steyer et al. 2011). Some studies have reported HAstV concentration by using qPCR and that ranges from $2.8 \times 10^{1} \mathrm{GC} / \mathrm{L}$ to $1.0 \times 10^{3} \mathrm{GC} / \mathrm{L}$ (Pusch et al., 2005; Liang et al., 2015). 
Table 3. Natural occurrence of Rotavirus in superficial water

\begin{tabular}{|c|c|c|c|c|c|}
\hline Area & Study Period & Genotypes & Percent Positive & $\begin{array}{c}\text { Concentrations Averages } \\
\text { (ranges), GC/L }\end{array}$ & Reference \\
\hline Brazil & 1987-1988 & NR & $\begin{array}{l}34.5 \% \\
(19 / 55)\end{array}$ & $<3.0$ to $54 \mathrm{FFU} / \mathrm{L}^{\mathrm{a}}$ & $\begin{array}{l}\text { Mehnert \& } \\
\text { Stewien, } 1993\end{array}$ \\
\hline $\begin{array}{l}\text { Brazil } \\
\text { (Manaus) }\end{array}$ & 2004-2005 & $\mathrm{G} 1, \mathrm{P}[4], \mathrm{P}[8]$ & $\begin{array}{l}44.2 \% \\
(23 / 52)\end{array}$ & NR & $\begin{array}{l}\text { Miagostovich } \\
\text { et al., } 2008\end{array}$ \\
\hline $\begin{array}{l}\text { Brazil } \\
\text { (Rio de Janeiro) }\end{array}$ & $2007-2008$ & P[4], SGII $d$ & $\begin{array}{c}24.3 \% \\
(35 / 144)\end{array}$ & $3.0 \mathrm{E}+01$ to $5.6 \mathrm{E}+04^{\mathrm{b}}$ & $\begin{array}{l}\text { Vieira et al., } \\
2012\end{array}$ \\
\hline $\begin{array}{l}\text { Brazil } \\
\text { (Rio de Janeiro) }\end{array}$ & 2008-2009 & NR & $\begin{array}{l}15.7 \% \\
(17 / 108)\end{array}$ & NR & $\begin{array}{l}\text { Miagostovich } \\
\text { et al., } 2014\end{array}$ \\
\hline $\begin{array}{l}\text { Brazil } \\
\text { (Florianópolis) }\end{array}$ & $2010-2011$ & NR & $\begin{array}{l}65.0 \% \\
(31 / 48)\end{array}$ & $1.2 \mathrm{E}+05$ to $2.5 \mathrm{E}+07$ & $\begin{array}{l}\text { Fongaro et al., } \\
2012\end{array}$ \\
\hline $\begin{array}{l}\text { Brazil } \\
\text { (Juiz de Fora) }\end{array}$ & 2011-2012 & ${ }^{\mathrm{I}}{ }^{\mathrm{e}}$ & $\begin{array}{r}62.5 \% \\
(30 / 48)\end{array}$ & $4.7 \mathrm{E}+02$ to $6.4 \mathrm{E}+04^{\mathrm{b}}$ & Assis et al., 2015 \\
\hline $\begin{array}{l}\text { Brazil } \\
\text { (Manaus) }\end{array}$ & 2011-2012 & NR & $\begin{array}{c}23.9 \% \\
(65 / 272)\end{array}$ & $5.66 \mathrm{E}+02$ to $1.35 \mathrm{E}+05$ & $\begin{array}{l}\text { Vieira et al., } \\
2016\end{array}$ \\
\hline (Bhinfling) & 2006-2007 & NR & (14/9\%) & NR & He et al., 2008 \\
\hline $\begin{array}{l}\text { China } \\
\text { (Beijing) }\end{array}$ & 2006-2007 & NR & $\begin{array}{c}48.1 \% \\
(52 / 108)\end{array}$ & Non-detect to $18.27^{b}$ & He et al., 2008 \\
\hline $\begin{array}{l}\text { Italy } \\
\text { (Otranto) }\end{array}$ & $2006-2007$ & $\mathrm{G} 1, \mathrm{G} 2$ & $\begin{array}{l}37.5 \% \\
(6 / 16)\end{array}$ & NR & Grassi et al., 2010 \\
\hline $\begin{array}{l}\text { Italy } \\
\text { (Pisa) }\end{array}$ & $2004-2005$ & $\mathrm{G} 1, \mathrm{G} 2, \mathrm{G} 4$ & $\begin{array}{l}33.5 \% \\
(4 / 12)\end{array}$ & NR & $\begin{array}{l}\text { Carducci et al., } \\
2006\end{array}$ \\
\hline $\begin{array}{l}\text { Kenya } \\
\text { (Maua, Nairobi, } \\
\text { Kibera) }\end{array}$ & $2007-2008$ & $\begin{array}{l}\mathrm{G} 1, \mathrm{G} 2, \mathrm{G} 3, \mathrm{G} 9 \\
\mathrm{G} 11, \mathrm{G} 12, \mathrm{P}[4] \\
\mathrm{P}[6], \mathrm{P}[8]\end{array}$ & $\begin{array}{l}44.8 \% \\
(13 / 29)\end{array}$ & NR & Kiulia et al., 2010 \\
\hline $\begin{array}{l}\text { Slovenia } \\
\text { (Throughout the } \\
\text { country) }\end{array}$ & 2008-2009 & G1, G3 & $\begin{array}{l}17.5 \% \\
(11 / 63)\end{array}$ & NR & $\begin{array}{l}\text { Steyer et al., } \\
2011\end{array}$ \\
\hline $\begin{array}{l}\text { South Africa } \\
\text { (King William's Town, } \\
\text { Zwelitsha, } \\
\text { Mdantsane and }\end{array}$ & 2010-2011 & NR & $\begin{array}{l}13.9 \% \\
(10 / 72)\end{array}$ & $2.5 \mathrm{E}+01$ to $2.1 \mathrm{E}+03^{\mathrm{b}}$ & $\begin{array}{l}\text { Chigor \& } \\
\text { Okor, } 2012\end{array}$ \\
\hline $\begin{array}{l}\text { Netherlands } \\
\text { (South Holland) }\end{array}$ & $2003-2005$ & NR & $\begin{array}{c}91.7 \% \\
(11 / 12)\end{array}$ & $\begin{array}{l}0.19(0.01-0.87) \text { to } \\
\quad 8.3(1.8-34.0)^{c}\end{array}$ & $\begin{array}{l}\text { Rutjes et al., } \\
2009\end{array}$ \\
\hline $\begin{array}{l}\text { USA } \\
\text { (Wisconsin) }\end{array}$ & $2001-2002$ & NR & $\begin{array}{l}66.7 \% \\
(8 / 12)\end{array}$ & NR & $\begin{array}{l}\text { Borchardt et } \\
\text { al., } 2004\end{array}$ \\
\hline $\begin{array}{l}\text { Venezuela } \\
\text { (Caracus) }\end{array}$ & $2007-2008$ & $\begin{array}{l}\text { G1, G10, } \\
\text { P[8] }\end{array}$ & $\begin{array}{l}89.0 \% \\
(16 / 18)\end{array}$ & NR & $\begin{array}{l}\text { Rodriguez-Diaz } \\
\text { et al., } 2009\end{array}$ \\
\hline \multicolumn{6}{|l|}{ NR - Not reported } \\
\hline \multicolumn{6}{|c|}{${ }^{\text {a }}$ Focus-forming unit } \\
\hline \multicolumn{6}{|l|}{${ }^{\mathrm{b}}$ Genome copies/L } \\
\hline \multicolumn{6}{|c|}{${ }^{\mathrm{c}}$ Infectious PCR detectable units per liter (PDU/L) } \\
\hline \multicolumn{6}{|c|}{${ }^{\mathrm{d}}$ Group A rotavirus classification in serogroups based on VP6 protein } \\
\hline${ }^{\mathrm{e}}$ Group A rotaviru & us VP6 genoty & sed on prot & 6 sequencing & & \\
\hline
\end{tabular}


Table 4. Natural occurrence of Astrovirus in superficial water

\begin{tabular}{|c|c|c|c|c|c|}
\hline Area & Study Period & Genotypes & Percent Positive & (ranges), GC/L & Reference \\
\hline $\begin{array}{l}\overline{\text { Brazil }} \\
\text { (Manaus) }\end{array}$ & 2004-2005 & HAstV-1 & $\begin{array}{l}15.4 \% \\
(8 / 52)\end{array}$ & NR & Miagostovich et al., 2008 \\
\hline $\begin{array}{l}\text { China } \\
\text { (Beijing) }\end{array}$ & 2006-2007 & HAstV-1 & $\begin{array}{l}5.6 \% \\
(6 / 108)\end{array}$ & NR & He et al., 2012 \\
\hline $\begin{array}{l}\text { France } \\
\text { (Cote } \\
\text { d'Opale) }\end{array}$ & $1999-2000$ & NR & $\begin{array}{l}2.9 \% \\
(2 / 68)\end{array}$ & NR & Hot et al., 2003 \\
\hline $\begin{array}{l}\text { France } \\
\text { (Paris) }\end{array}$ & 2013-2014 & NR & $\begin{array}{c}36.0 \% \\
(36 / 100)\end{array}$ & Non-detect to $E+04$ & Prevost et al. 2015, \\
\hline $\begin{array}{l}\text { Germany } \\
\text { (Leipzig) }\end{array}$ & $2002-2003$ & HAstV $(1,2)$ & $\begin{array}{l}23.7 \% \\
(9 / 38)\end{array}$ & Non-detect to $E+03$ & Pusch et al., 2005 \\
\hline $\begin{array}{l}\text { Kenya } \\
\text { (Maua } \\
\text { region) }\end{array}$ & $2007-2008$ & NR & $\begin{array}{l}41.7 \% \\
(5 / 12)\end{array}$ & NR & Kiulia et al., 2010 \\
\hline $\begin{array}{l}\text { Kenya } \\
\text { (Nairobi) }\end{array}$ & $2007-2008$ & NR & $\begin{array}{l}60.0 \% \\
(6 / 10)\end{array}$ & NR & Kiulia et al., 2010 \\
\hline $\begin{array}{l}\text { Singapore } \\
\text { (Southern } \\
\text { Singapore) }\end{array}$ & 2011-2013 & NR & $\begin{array}{l}22.6 \% \\
(21 / 93)\end{array}$ & 28 to 65 & Liang et al., 2015 \\
\hline Slovenia & 2008-2009 & NR & $\begin{array}{c}27 \% \\
(17 / 63)\end{array}$ & NR & Steyer et al. 2011 \\
\hline
\end{tabular}




\subsubsection{Groundwater}

RVA detection in a groundwater system was described in France, in 2000, during a large multi-pathogen waterborne community outbreak linked to fecal contamination. Genotype 1 (G1) was found in stools and water indicating a human faecal source of infection (Gallay et al., 2006). RVA was also detected as the dominant pathogen (40\% [20/50]) in groundwater filtrates collected from tubewells in rural Bangladesh for a study comparing fecal indicators with pathogenic bacteria and RV in groundwater pumped from shallow tubewells (Ferguson et al., 2012). In a study conducted in Slovenia, HAstV was detected in $1.4 \%$ of the groundwaters analyzed, which were used as a source of drinking water (Steyer et al., 2011).

\subsubsection{Drinking water}

The first occurrence of RVA in conventionally treated drinking water was described in Guadalajara, Mexico. The frequency of RVA was higher during the rainy season, when $100 \%(10 / 10)$ of drinking water samples contained infectious RVA in concentration ranging from 16 to 210 imunofluorescent (IF) foci/20L. In the dry season RVA was isolated in $14 \%(3 / 21)$, with 1.2 to 125 IF foci/L (Deetz et al., 1984). In a more extensive study for the removal of viruses by water treatment process in a full-scale water treatment plant, RV was also isolated in 2 out of 9 finished water samples (Keswick et al., 1984). In a study conducted in Albania, RVA occurrence in drinking water was monitored in association with outbreaks resulting from contamination of groundwater or surface waters. In the city of Lac, RVA was identified by RT-PCR in two out of five drinking water samples that were collected during an outbreak of hepatitis A, probably due to the contamination of drinking water by sewage. RVA was also identified in three out of five sewage samples, (while 4 of those samples were also positive for hepatitis A virus (Divizia et al., 2005). In Slovenia, RVA was detected in 30.3\% (27/89) and in $37.5 \%(27 / 72)$ of drinking water and potable groundwater samples respectively, suggesting that raw groundwater used as an individual drinking water supply may be a possible source of enteric virus infections (Steyer, et al., 2011). In an attempt to determine the role of drinking water in the occurrence of RVA infection in an epidemic period, a prospective study was conducted in three towns in the southeast France. From 56 samples of drinking water samples collected from the homes of 56 children who had been hospitalized for RVA acute gastroenteritis, 7\% (4/56) were positive for RVA. In a monitoring study carried out in Brazil enteric viruses were investigated from tap water in 73 public schools at six municipalities of the southern region, being RVA detected in rates ranging from $8.3 \%$ to $30 \%$ according to the municipalities (Kluge et al., 2014). For HAstV, only few studies have described their occurrence in drinking water. In Slovenia, HAstV was detected in $5.9 \%$ of the drinking water samples analyzed from the public water supply (Steyer et al., 2011) and the virus was detected in $2 \%$ of chlorinated tap water samples with low levels of residual chlorine (France (Gofti-Laroche et al., 2003).

\subsubsection{Seawater}

Studies on seawater of the Brazilian coast showed RVA detection ranging from $16 \%$ to $50 \%$ in different regions. The highest detection was reported during a one year of virus monitoring (2007-2008) conducted in Florianópolis, in the southern region of Brazil (Rigotto et al., 2010). In Rio de Janeiro, the southeast region of the country characterized by high temperatures throughout the year, RVA was detected in 16\% (2/12) during 2007-2008 and 37\% $(27 / 74)$ in 2012 , with virus concentration ranging between $3.0 \times 10^{1}$ to $5.6 \times 10^{4} \mathrm{GC} / \mathrm{L}$ (Vieira et al., 2012; Victoria et al., 2014). The data on the occurrence of HAstV in seawater are limited but reveal an environmental dissemination as observed in Japan, where HAstV was detected in $12 \%$ of the samples (14/120) collected during one year from April 1999 to March 2000 from at a yacht harbor in Chiba city (Yokoi et al., 2001).

\subsubsection{Irrigation water and on crops}

In a study performed in Mexico, RVA was detected in $21.2 \%(7 / 33)$ of vegetables samples obtained in a market including 5 celery [Apium graveolus], 6 coriander [Coriandrum sativum], 6 spinach [Spinacea oleracea], 6 romaine lettuce [Lactuca sativa], 5 papaloquelite [Porophyllum ruderale], and 5 parsley [Petroselinum hortense]. RVA genotypes G2 and P[4] were detected (Quiroz-Santiago et al., 2014). In another study, Van Zyl et al. (2006) screened the presence of RVA in raw and treated drinking water supplies samples, besides selected irrigation water and corresponding raw vegetables in three regions of southern Africa. The results show the detection of RVA in partially treated water (11.8\%), finally treated drinking water $(17 \%)$, irrigation water (14\%) and corresponding raw vegetable samples (1.7\%). The presence of multiple types (G1, G2, G8, and G9) in irrigation water and single types (G1 or G3) for VP7 gene and mixed P types (P[4], P[6], P[8], and $P[9])$ was observed. In another study, RVA and HAstV were detected in water used for irrigation in farms to cultivate flowers and vegetables in the south of Mexico City during the cold-dry seasons of 2001 and 2002 (Espinosa et al., 2009).

\subsubsection{Shellfish and fish}

Over the past decades, RVA genome has been detected in shellfish (oysters, clams, and mussels) obtained directly from different aquatic environments such as marine farms and mangroves. In a three-year study performed in southern France (1995-1998), RVA was detected in $27 \%$ of oyster (Crassostrea gigas) and in 52\% of mussels (Mytilus galloprovincialis) collected in areas routinely impacted by human sewage. (Le Guyader et al., 2000). In another study, RVA detection was performed in 63 samples: 30 oysters (Crassostrea virginica) and 33 vegetables (five celery 
[Apium graveolus], six coriander [Coriandrum sativum], six spinach [Spinacea oleracea], six romaine lettuce [Lactuca sativa], five papaloquelite [Porophyllum ruderale], and five parsley [Petroselinum hortense]) obtained from the Central Food Supply Station of Mexico City. RVA was detected in 17 (26.9\%) samples; 10 oysters and 7 vegetables. (QuirozSantiago et al., 2014). In Italy, RVA was found in $25.5 \%$ (35/113) of the molluscan shellfish from 62 samples collected for environmental monitoring and from 67 for sale, including mussels, clams and oysters obtained from Greece, France, and Italy (Gabrieli et al., 2007). In Thailand, 110 oyster samples were collected and RVA was detected $5.4 \%(6 / 110)$ of the samples analyzed (Kittigul et al., 2014). In another study that used specific, sensitive and high-throughput gene chip technology RVA were detected in $6.2 \%$ of shellfish samples from the main coastal cities of China (Ming et al., 2014). In Brazil, RVA was detected in $8.3 \%$ (2/24) of the $C$. gigas cultivated in marine farms in the city of Florianópolis, in the southern region of the country (Rigotto et al., 2010). In Brazilian mangroves, RVA genome was detected by nRT-PCR in $100 \%$ of the mussels studied (Keller et al., 2013) and in Japan RVA were detected in $1.2 \%(1 / 88)$ of oyster-associated RVA gastroenteritis outbreak (Iritani et al., 2014). In order to highlight the possibility that shellfish can become a vehicle of viral transmission even when the bacterial indicators are below the regulatory limits, an experimental study "in field", using RVA and Mytilus galloprovincialis, was performed in a costal bay of Italy. After seven days it was demonstrated that $E$. coli was detected with low values ranging from 8.65 MPN/100 $\mathrm{g}$ to $35.0 \mathrm{MPN} / 100 \mathrm{~g}$ which is below the limits set in the Regulation (EC) 854/2004 in all studied points. However, RVA genome was detected in hepatopancreas of the mussels at the third week post contamination, suggesting RVA as a viral indicator to ensure the safety for consumption of shellfish (Bagordo et al., 2013). Regarding $\mathrm{HAstV}$, detection rate in shellfish ranged from $6 \%$ to $61 \%$ where the main species studied were pacific oysters (Crassostrea gigas),clams and mussels (Elamri et al., 2006; Ming et al., 2014). In a three year-study conducted in the south of France, HAstV was detected in $17 \%$ of oysters located at areas occasionally impacted by sewage and in $37 \%$ of mussels collected in areas subjected to sewage discharge. It was observed a seasonality pattern of HAstV presence, with a very low detection during summer and high detection during winter. A good correlation between bacterial and enteric viruses contamination was observed in sites heavily impacted by sewage but no correlation was observed in sites occasionally contaminated by sewage discharge (Le Guyader et al., 2000). Quantification of HAstV in oysters (Crassostrea gigas) after a rainfall event in France revealed a concentration of $10^{4} \mathrm{GC} / 100 \mathrm{gr}$ (Riou et al., 2007).

\subsubsection{In the air (aerosol) and surfaces (fomites)}

Recovery infectious particles of RVA from hands, surfaces and fomites showed that animate and inanimate surfaces could play a complementary role in the spread of those viruses (Sattar et al., 1994). For example, toys shared in a pediatric oncology unit hospital in New York have been implicated fomites in the transmission of a nosocomial RVA outbreak (Rogers et al., 2000). In another study, RVA was detected by nested RT-PCR in 14\% (73/504) of surface samples obtained from an adult intensive care unit in a hospital in Rio de Janeiro (Brazil), with viral loads ranging from 3.4 to $2.9 \times 10^{3} \mathrm{GC} / \mathrm{mL}$. RVA infectivity was demonstrated by analysing these samples with an integrated cell culture/RT-PCR (Ganime et al., 2012).

\subsection{Persistence}

RVA is stable both in environments with low and high relative humidity and $\mathrm{pH}$ ranging from 3 to 9 . This virus is also thermostable between $50^{\circ} \mathrm{C}$ and $56^{\circ} \mathrm{C}$ although it can be damaged by repetitive cycles of freezing and defrosting (Sattar et al., 1984; Kapikian et al., 2001; Steele et al., 2004). In tap water held at $4^{\circ} \mathrm{C}$, there was no significant drop in RVA virus titer even after 64 days, whereas at $20^{\circ} \mathrm{C}$ the titer was reduced by about $2 \log _{10}$ over the same period. Even though the loss of virus infectivity was faster in river waters held at $20^{\circ} \mathrm{C}$, it took about 10 days for a 2 $\log _{10}$ reduction in the plaque titer of the virus (Raphael et al., 1985). Abad et al. (1994) evaluated the survival of RVA on porous (paper and cotton cloth) and non porous (aluminum, toilet china porcelain, glazed tile, latex, and polystyrene) environmental surfaces at two different temperatures $\left(4^{\circ} \mathrm{C}\right.$ and $\left.20^{\circ} \mathrm{C}\right)$ demonstrating that they can persisted for extended periods ( $\sim 60$ days) on these types of materials at both temperatures. Persistence studies of HAstV have been conducted in fomites, groundwater, surface and drinking water. Table 5 shows the time required for reduction of $2 \log _{10}$ in accordance to the matrix and the measured temperature associated to other conditions. In groundwater (at $15^{\circ} \mathrm{C}$ ), the viral infectivity was reduced by about $1 \log _{10}$ at day 30 as compared to a 4 $\log _{10}$ reduction during the same period of time in surface water (at room temperature); nevertheless, the reduction of virus infectivity was not significant during the first 15 days of incubation in groundwater. A reasonably good correlation was found between virus infectivity and the presence of viral genome in surface water suggesting that detection of viral genome material can be an adequate indicator of virus contamination in surface water (Espinosa et al., 2008). 
Table 5. Effect of temperature on survival of Astrovirus in water and surfaces

\begin{tabular}{|c|c|c|c|c|}
\hline$\sim$ Time for $2 \log _{10}$ reductions (days) & Temperature ${ }^{\circ} \mathrm{C}$ & Matrix & Other conditions & Reference \\
\hline 15 & $\begin{array}{c}\text { Room } \\
\text { temperature }\end{array}$ & $\begin{array}{l}\text { surface } \\
\text { water }\end{array}$ & NR & $\begin{array}{c}\text { Espinosa } \\
\text { et al., } \\
2008\end{array}$ \\
\hline 45 & 15 & groundwater & NR & $\begin{array}{c}\text { Espinosa } \\
\text { et al., } \\
2008\end{array}$ \\
\hline 6 & 4 & $\begin{array}{l}\text { toilet china } \\
\text { surface }\end{array}$ & $\begin{array}{l}\text { in } 20 \% \text { fecal } \\
\text { suspension }\end{array}$ & $\begin{array}{l}\text { Abad et } \\
\text { al., } 2001\end{array}$ \\
\hline 1 & 20 & $\begin{array}{l}\text { toilet china } \\
\text { surface }\end{array}$ & $\begin{array}{l}\text { in } 20 \% \text { fecal } \\
\text { suspension }\end{array}$ & $\begin{array}{l}\text { Abad et } \\
\text { al., } 2001\end{array}$ \\
\hline 3 & 4 & $\begin{array}{l}\text { cellulose } \\
\text { filter paper }\end{array}$ & $\begin{array}{l}\text { in } 20 \% \text { fecal } \\
\text { suspension }\end{array}$ & $\begin{array}{l}\text { Abad et } \\
\text { al., } 2001\end{array}$ \\
\hline$<1$ & 20 & $\begin{array}{c}\text { cellulose } \\
\text { filter paper }\end{array}$ & $\begin{array}{l}\text { in } 20 \% \text { fecal } \\
\text { suspension }\end{array}$ & $\begin{array}{l}\text { Abad et } \\
\text { al., } 2001\end{array}$ \\
\hline 60 & 4 & $\begin{array}{l}\text { drinking } \\
\text { water }\end{array}$ & NR & $\begin{array}{l}\text { Abad et } \\
\text { al., } 1997\end{array}$ \\
\hline 22 & 20 & $\begin{array}{l}\text { drinking } \\
\text { water }\end{array}$ & NR & $\begin{array}{l}\text { Abad et } \\
\text { al., } 1994\end{array}$ \\
\hline
\end{tabular}

NR - Not reported

\subsection{Reductions by Sanitation Management}

\subsection{Wastewater Management}

\subsubsection{Onsite waterless sanitation}

RVA was not inactivated in urine at low temperature $\left(5^{\circ} \mathrm{C}\right)$, whereas at $20^{\circ} \mathrm{C}$ the $\mathrm{T}_{90}$-value was 35 days (Höglund et al., 2001).

\subsubsection{Water-based sanitation - onsite}

Two studies performed with septic tank demonstrated that the use of this sanitation tool represents a risk of infection being associated with cases of RVA diarriea. In the White Mountain Apache reservation, USA, the presence of a septic tank within a household was identified as a major cause of RVA-associated diarrhea (Menon et al., 1990). The long-term use of a filter-based, on-site wastewater treatment system increases nutrient discharge to receiving waters and may reduce its hygienic barrier efficiency. In Norway, based on removal of bacteriophages, it was estimated high RVA infection risk $(>1 / 10,000$ per annum) for children that accidentally ingest $1-2 \mathrm{~mL}$ of the effluent of a septic tank receiving wastewater from single households (Heistad et al., 2009).

\subsubsection{Waste water stabilization and aerated ponds}

RVA reduction of $99.7 \%$ was achieved using anaerobic, facultative and maturation ponds in two series receiving domestic wastewater in Egypt. (Mahassen et al. 2008).

\subsubsection{Wetlands}

By using a surface constructed wetland for the treatment of the effluent of a wastewater treatment plant in Sweden, Westrell(2004) described a quantitatively assessment of the RVA infection associated to two exposure scenarios: i) unintentional contact at the inlet of the wetland and ii) children playing at the outlet of the wetland. The total RVA exposure per day was assumed to be 0.1 and 0.001 for the two scenarios (influent and effluent represent $2 \log _{10}$ reduction by the wetlands). WHO has developed a tolerable health risk for drinking water of $10^{-4}$ annual risk (see QMRA section). For RVA, unintentional immersion at wetland inlet ( $30 \mathrm{~mL}$ for 1 time per year) represented a risk of $5 \times 10^{-2}$ annual risk of infection and children playing at wetland inlet $(1 \mathrm{~mL}$ for 2 times per year), $2 \times 10^{-3}$ annual risk of infection. This method represents medium level of risk for the worker at surface flow wetlands at the inlet part and for the community (depending on the design and location) for surface flow wetlands and lot at the outlets and for subsurface flow wetlands. 


\subsubsection{Wastewater treatment facilities}

$\log _{10}$ removals or reduction of RVA and HAstV have been evaluated from wastewater treatment plants (WWTPs) and may vary according to the type of the wastewater treatment process, season and geographical area (Tables 6, 7). Li et al. (2011) examined RVA removal and inactivation using two techniques for detection of the virus namely; RTPCR and ICC-RT-qPCR in three different treatment plants from Beijing, China. Activated sludge treatment produced a mean RV removal ranging between 2 and $2.83 \log _{10}$ where as coagulative precipitation produced a mean removal of $0.72 \pm 0.08 \log _{10}$. In general, secondary treatment reduced the virus concentrations with removal ranging between 0.8-2.5 $\log _{10}$ (Kiulia et al., 2015). However, anaerobic treatment processes (UASB - Upflow Anaerobic Sludge Blanket, filters and anaerobic digester followed by posttreatment by anaerobic ponds) were not able to achieve such viral removal efficiencies. Hmaied et al. (2015) reported data on the performance of a laboratory scale "Submerged Membrane Bioreactor" (SMBR) in Tunisia, treating abattoir wastewaters for RVA removal. All effluent samples, which fed the SMBR, were positive for RVA with concentrations ranging among $5.2 \times 10^{5}$ to $1.3 \times 10^{7} \mathrm{GC} / \mathrm{L}$, showing limited removal by the conventional biological process for RVA. However, after SMBR treatment no viruses were detected with 5 to $7 \log _{10}$ removals described during treatment. The researchers also provided evidence that removal of RVA was similar to that of total coliphages by SMBR. Several studies have been performed to determine the removal rate of HAstV in WWTP with an activated sludge process. In a study conducted in Brazil, the HAstV removal reached $3 \log _{10}$; present at mean concentration of $1.8 \times 10^{3} \mathrm{GC} / \mathrm{L}$ in influent and absent in the effluent (Fumian et al., 2013). In other study, Le Cann et al. (2004) detected a mean of $4.1 \times 10^{7} \mathrm{GC} / \mathrm{L}$ in influent and $1.0 \times 10^{5} \mathrm{GC} / \mathrm{L}$ in effluent registering a HAstV removal of 2.7 $\log _{10}$. In a recent study, a WWTP with activated sludge process followed by chlorination and sand filtration with a hydraulic retention time of $9.3 \mathrm{~h}$ was analyzed for HAstV removal. The virus was present in influent at concentrations ranging from $10^{4}$ to $10^{5} \mathrm{GC} / \mathrm{L}$, in secondary treated wastewater (after activated sludge process) and chlorinated wastewater samples ranged from $10^{2}$ to $10^{3} \mathrm{GC} / \mathrm{L}$ and in effluent samples (after sand filtration) ranged from $10^{1}$ to $10^{2} \mathrm{GC} / \mathrm{L}$. The highest HAstV reduction was observed after the activated sludge process and the mean reduction of the whole process was $2.4 \log _{10}$ (Hata et al., 2015). Similar results were observed by Morsy ElSenousy et al. (2007) who studied the reduction of HAstV concentration in three different WWTP in Egypt. They found that activated sludge treatment and/or chlorination in combination with primary sedimentation were more effective for HAstV removal than primary sedimentation alone. When examining the various processes and over all removal rates of HAstV, these ranged from $1.0 \log _{10}$ to 5.1 $\log _{10}$ in water reclamations plants using primary sedimentation plus activated sludge (El-Senousy et al., 2007; Aw et al., 2010). 
Table 6. Rotavirus removal/inactivation data for wastewater treatment plants

\begin{tabular}{|c|c|c|c|c|c|c|}
\hline Area & Period of Study & Treatment process(es) & Samples & $\begin{array}{l}\text { Removal/ } \\
\text { inactivation } \\
\text { Mean (log10) }\end{array}$ & $\begin{array}{l}\text { Stdev } \\
(\log 10)\end{array}$ & Reference \\
\hline Egypt & $2009-2011$ & $\begin{array}{l}\text { Activated sludge, primary } \\
\text { and secundary } \\
\text { sedimentation, chlorination }\end{array}$ & 96 & NR & NR & $\begin{array}{l}\text { Morsy El- } \\
\text { Senousy et } \\
\text { al., } 2015\end{array}$ \\
\hline Tunisia & NR & $\begin{array}{l}\text { Membrane Bioreactor } \\
\text { Technology }\end{array}$ & 24 & 5.0 & NR & $\begin{array}{l}\text { Hmaied et } \\
\text { al., } 2015\end{array}$ \\
\hline China & $2007-2008$ & $\begin{array}{l}\text { Coagulative precipitation } \\
\text { and sand filtration }\end{array}$ & 12 & 0.72 & 0.08 & \\
\hline China & $2007-2008$ & $\begin{array}{l}\text { Aerated grit chamber and } \\
\text { Primary setting, A2 / O } \\
\text { activated sludge (Retention } \\
\text { time: } 6 \text { h), and secondary } \\
\text { setting, Reverse osmosis } \\
\text { membrane ultrafiltration }\end{array}$ & 12 & 2 & 1.1 & $\begin{array}{l}\text { Li et al., } \\
2011\end{array}$ \\
\hline China & $2007-2008$ & $\begin{array}{l}\text { Aerated grit chamber and } \\
\text { Primary setting, Activated } \\
\text { sludge process (retention time: } \\
5 \mathrm{~h} \text { ), and secondary setting, } \\
\text { Coagulative precipitation and } \\
\text { sand filtration }\end{array}$ & 12 & 2.08 & 0.63 & \\
\hline China & $2007-2008$ & $\begin{array}{c}\text { Aerated grit chamber and } \\
\text { primary setting , Anaerobic- } \\
\text { anoxic-oxic (A2 /O) activated } \\
\text { sludge (Retention time: } 6 \mathrm{~h}), \\
\text { and secondary setting } 0,02 \mu \mathrm{m} \\
\text { hollow fibre membrane } \\
\text { ultrafiltration }\end{array}$ & 12 & 2.83 & 0.49 & \\
\hline
\end{tabular}

NR - Not Reported

Table 7. Astrovirus removal/inactivation data for wastewater treatment plants

\begin{tabular}{|c|c|c|c|c|c|c|}
\hline Area & Period of Study & Treatment Process(es) & Samples & $\begin{array}{c}\text { Removal/ } \\
\text { inactivation } \\
\text { Mean (log10) }\end{array}$ & $\begin{array}{c}\text { Stdev } \\
(\log 10)\end{array}$ & Reference \\
\hline Brazil & $2009-2010$ & Activated sludge & 48 & 3.0 & NR & $\begin{array}{l}\text { Fumian et al., } \\
2013\end{array}$ \\
\hline France & $2009-2010$ & Biological treatment & 34 & 2.0 & NR & $\begin{array}{l}\text { Le Cann et } \\
\text { al., } 2004\end{array}$ \\
\hline Egypt & 1998-1999 & $\begin{array}{l}\text { Primary sedimentation } \\
\text { activated sludge } \\
\text { chlorination }\end{array}$ & 13 & 3.8 & 1.2 & $\begin{array}{l}\text { Morsy El- } \\
\text { Senousy } \\
\text { et al., } 2007\end{array}$ \\
\hline Japan & $2007-2008$ & $\begin{array}{c}\text { Activated sludge } \\
\text { with chlorination and sand } \\
\text { filtration }\end{array}$ & 24 & 2.4 & 0.3 & Hata et al., 2015 \\
\hline Singapore & 2007 & Activated sludge & 36 & 3.0 & NR & Aw et al. 2010 \\
\hline
\end{tabular}

NR- Not Reported 


\subsection{Disinfection}

\subsubsection{Chlorination}

RVA are resistant to chlorine and may persist for extend period under a variety of environmental conditions (Melnick et al., 1978). The effects of free chlorine disinfection of tap water and wastewater effluents on the infectivity, gene integrity and surface antigens of RVA and HAstV have been reported. In a study conducted in Mexico in 1978, RVA was detected in $100 \%(10 / 10)$ of driking water samples (Deetz et al., 1984). Using the simian strain SA11, Li et al. (2011) demonstrated RVA infectivity after chlorination at dose up to $20 \mathrm{mg} / \mathrm{L}$ (60 min contact). By the use of cell culture and RT-PCR aiming to assess infectivity and genetic integrity of RVA isolates after chlorine and $\mathrm{ClO}_{2}$ treatment, Xue et al. (2013) showed the higher disinfection efficacy of the $\mathrm{ClO}_{2}$ According to the efficiency, factor Hom model, $\mathrm{Ct}$ value $(\mathrm{mg} / \mathrm{L} \mathrm{min})$ ranges required for a $4 \log _{10}$ reductions of RVA at $20^{\circ} \mathrm{C}$ by chlorine and $\mathrm{ClO}_{2}$ were 5.55-5.59 and 1.21-2.47 $\mathrm{mg} / \mathrm{L} \mathrm{min}$, respectively. In this study, the authors showed no correlation between culturing and RT-PCR assays after treatment of RVA with $\mathrm{ClO}_{2}$, suggesting that the current chlorine disinfection process may be inadequate to manage the risk of waterborne RVA infections. El-Senousy et al. (2014) conducted a study in Egypt in which human and animal RVA (Wa and SA11 strains) were exposed to different chlorine concentrations in inoculated Nile river water and drinking water samples. Both human and animal RVA were more resistant to chlorine in drinking water where only $3 \log _{10}$ reduction under $3 \mathrm{mg} / \mathrm{l}$ for $15 \mathrm{~min}$ was observed while $5 \log _{10}$ reduction was observed under exposure to $4 \mathrm{mg} / \mathrm{l}$ for 15 min. In a study conducted in Arizona, USA, Kitajima et al. (2014) showed RVA removal by chlorination after post secondary treatment ranging between a mean of 0.7 to 2.56 $\log _{10}$. In general, secondary treatment reduced the virus concentrations with removal ranging between 0.8-2.5 $\log _{10}$ (Kiulia et al., 2015). For HAstV, Abad et al. (1997) demonstrated a $2.5 \log _{10}$ titer infectivity reduction after 1 $\mathrm{hr}$. in drinking water with $0.5 \mathrm{mg} / \mathrm{L}$ of free chlorine. While at a higher concentration, (1 $\mathrm{mg} / \mathrm{L})$ residual infectivity was observed after $2 \mathrm{~h}$ with a $\log _{10}$ titer reduction of 4.1 . In another study, where HAstV-8 strain was inoculated in groundwater, a decrease of infectivity was evidenced with $1.3 \log _{10}$ reduction after $2 \mathrm{~h}$ with $2 \mathrm{mg} / \mathrm{L}$ (Espinosa et al., 2008).

\subsubsection{On fomites}

The RVA infectivity remains on porous (paper and cotton cloth) and nonporous surfaces (aluminum, latex) (Abad et al., 1994). Virus infectivity decreases significantly by the action of chelating agents such as ethylenediaminetetraacetic acid (EDTA), at basic pH levels (above 10), by treatment with sodium dodecyl sulfate (SDS), and ultraviolet (UV) (Ward \& Ashley, 1980; Kapikian et al., 2001, Li et al., 2009). Ethanol, lysol, phenol and formalin are suitable disinfectants (Steele et al., 2004), while ether, chloroform, ammonia or sodium hypochlorite treatment are not efficient RVA inactivation agents. 95\%ethanol is a very effective disinfectant, once it has the ability to remove the outer capsid of viral particle (Kapikian et al., 2001). Other effective agents in RVA inactivation are: $37 \%$ formaldehyde (1:10), 0.75\% hexachlorophene (1:3) and chloramine-T 67\% (1:5) (Steele et al., 2004).

\subsubsection{Thermal inactivation}

RVA is shown to be thermostable between $50^{\circ} \mathrm{C}$ and $56^{\circ} \mathrm{C}$ although it can be damaged by repetitive cycles of freezing and defrosting (Sattar et al., 1984; Kapikian et al., 2001; Steele et al., 2004). HAstV are stable at pH 3.0 and resistant to a wide variety of detergents and lipid solvents. They keep their viability after five minutes at $60^{\circ} \mathrm{C}$ and also when stored at $-80^{\circ} \mathrm{C}$ for a period of 10 years, but they are unstable when they undergo thawing (Mendez \& Arias, 2007). 


\section{References}

Abad, F.X., Pinto, R.M. and Bosch, A. (1994). Survival of enteric viruses on environmental fomites. Applied and Environmental Microbiology. 60, pp. $3704-3710$.

Abad, F.X., Pinto, R.M., Villena, C., Gajardo, R. and Bosch, A. (1997). Astrovirus survival in drinking water. Applied and Environmental Microbiology. 63, pp. 3119-3122.

Abad, F.X., Villena, C., Guix, S., Caballero, S., Pinto, R.M. and Bosch, A. (2001). Potential role of fomites in the vehicular transmission of human astroviruses. Applied and Environmental Microbiology. 67, pp. 3904-3907.

Abbaszadegan, M., Ghatpande, P., Brereton, J., Alum, A. and Narasimhan, R. (2003). Laboratory testing protocol to identify critical factors in bacterial compliance monitoring. Water Science and Technology. 47, pp. 131-136.

Agbalika, F., Wullenweber, M. and Prévot, J. (1985). Preliminary evaluation of the ELISA as a tool for the detection of rotaviruses in activated sewage sludge. Zentralblatt für Bakteriologie, Mikrobiologie und Hygiene. 1 Abt. Originale B. 180(5-6), pp. 534-539.

Akihara, S., Phan, T.G., Nguyen, T.A., Hansman, G., Okitsu, S. and Ushijima, H. (2005). Existence of multiple outbreaks of viral gastroenteritis among infants in a day care center in Japan. Archives of Virology. 150(10), pp. 2061-2075.

Anderson, E.J., Shippee, D.B., Tate, J.E., Larkin, B., Bregger, M.D., Katz, B.Z. et al. (2015). Clinical characteristics and genotypes of rotavirus in adults. The Journal of Infection. 70, pp. 683-687. doi: 10.1016/j.jinf.2014.11.012.

Anderson, E.J. and Weber, S.G. (2004). Rotavirus infection in adults. The Lancet. Infectious Diseases. 4, pp. 91-99. doi: 10.1016/S1473-3099(04)00928-4.

Ansari, S.A., Sattar, S.A., Springthorpe, V.S., Wells, G.A. and Tostowaryk, W. (1988). Rotavirus survival on human hands and transfer of infectious virus to animate and nonporous inanimate surfaces. Journal of Clinical Microbiology. 26, pp. 1513-1518.

Ansari, S.A., Springthorpe, V.S. and Sattar, S.A. (1991). Survival and vehicular spread of human rotaviruses: possible relation to seasonality of outbreaks. Review of Infectious Diseases. 13, pp. $448-461$.

Assis, A., Cruz, L., Ferreira, A., Bessa, M., Pinto, M., Vieira, C. et al. (2015). Relationship between viral detection and turbidity in a watershed contaminated with group A rotavirus. Environmental Science and Pollution Research. 22(9), pp. 6886-6897. doi: 10.1007/s11356-014-3874-8.

Aw, T.G. and Gin, K.Y. (2010). Environmental surveillance and molecular characterization of human enteric viruses in tropical urban wastewaters. Journal of Applied Microbiology. 109, pp. 716-730.

Bányai, K., László, B., Duque, J., Steele, A.D., Nelson, E.A., Gentsch, J.R. et al. (2012). Systematic review of regional and temporal trends in global rotavirus strain diversity in the pre rotavirus vaccine era: insights for understanding the impact of rotavirus vaccination programs. Vaccine. 30 Suppl 1, pp. A122-A130. doi: 10.1016/j.vaccine.2011.09.111.

Bagordo, F., Grassi, T., Idolo, A., Serio, F., Gabutti, G. and De Donno, A. (2013). Rotavirus Occurrence in Shellfish with Low Levels of E. coli. Food and Environmental Virology.

Barman, P., Ghosh, S., Das, S., Varghese, V., Chaudhuri, S., Sarkar, S. et al. (2004). Sequencing and sequence analysis of VP7 and NSP5 genes reveal emergence of a new genotype of bovine group B rotaviruses in India. Journal of Clinical Microbiology. 42, pp. 2816-2818. doi: 10.1128/JCM.42.6.2816-2818.2004.

Barreto, M.L., Milroy, C.A., Strina, A., Prado, M.S., Leite, J.P., Ramos, E.A. et al. (2006). Community-based monitoring of diarrhea in urban Brazilian children: incidence and associated pathogens. Transactions of the Royal Society of Tropical Medicine and Hygiene. 100, pp. 234-242.

Barril, P.A., Fumian, T.M., Prez, V.E., Gil, P.I., Martínez, L.C., Giordano, M.O. et al. (2015). Rotavirus seasonality in urban 
sewage from Argentina: effect of meteorological variables on the viral load and the genetic diversity. Environmental Research. 138, pp. 409-415. doi: 10.1016/j.envres.2015.03.004.

Barril, P.A., Giordano, M.O., Isa, M.B., Masachessi, G., Ferreyra, L.J., Castello, A.A. et al. (2010). Correlation between rotavirus A genotypes detected in hospitalized children and sewage samples in 2006, Córdoba, Argentina. Journal of Medical Virology. 82, pp. 1277-1281. doi: 10.1002/jmv.21800.

Belliot, G., Laveran, H. and Monroe, S.S. (1997). Outbreak of gastroenteritis in military recruits associated with serotype 3 astrovirus infection. Journal of Medical Virology. 51, pp. 101-106.

Bernstein, D.I. (2009). Rotavirus overview. The Pediatric Infectious Disease Journal. 28, pp. S50-S53. doi: 10.1097/INF.0b013e3181967bee.

Bibby, K. and Peccia, J. (2013). Identification of viral pathogen diversity in sewage sludge by metagenome analysis. Environmental Science and Technology. 47, pp. 1945-1951.

Bishop, R.F. (1996). Natural history of human rotavirus infection. Archives of Virology. Supplementum. 12, pp. 119-128. doi: 10.1007/978-3-7091-6553-9_14.

Bishop, R.F., Davidson, G.P., Holmes, I.H. and Ruck, B.J. (1973). Virus particles in epithelial cells of duodenal mucosa from children with acute non-bacterial gastroenteritis. Lancet. 2, pp. 1281-1283.

Block, S.L., Vesikari, T., Goveia, M.G., Rivers, S.B., Adeyi, B.A., Dallas, M.J. et al. (2007). Efficacy, immunogenicity, and safety of a pentavalent human-bovine (WC3) reassortant rotavirus vaccine at the end of shelf life. Pediatrics. 119, pp. $11-18$.

Borchardt, M.A., Haas, N.L. and Hunt, R.J. (2004). Vulnerability of drinking-water wells in La Crosse, Wisconsin, to entericvirus contamination from surface water contributions. Applied and Environmental Microbiology. 70, pp. 5937-46. doi: 10.1128/AEM.70.10.5937-5946.2004.

Bosch, A., Pintó, R.M. and Guix, S. (2014). Human astroviruses. Clinical Microbiology Reviews. 27, pp. 1048-1074. doi: 10.1128/CMR.00013-14.

Braeye, T., De Schrijver, K., Wollants, E., Van Ranst, M. and Verhaegen, J. (2015). A large community outbreak of gastroenteritis associated with consumption of drinking water contaminated by river water, Belgium, 2010. Epidemiology and Infection. 143, pp. 711-719.

Brinker, J.P., Blacklow, N.R. and Herrmann, J.E. (2000). Human astrovirus isolation and propagation in multiple cell lines. Archives of Virology. 145, pp. 1847-1856.

Bucardo, F., Lindgren, P.E., Svensson, L. and Nordgren, J. (2011). Low prevalence of rotavirus and high prevalence of norovirus in hospital and community wastewater after introduction of rotavirus vaccine in Nicaragua. PLoS one. 6, pp. e25962.

Caballero, S., Guix, S., Ribes, E., Bosch, A. and Pinto, R.M. (2004). Structural requirements of astrovirus virus-like particles assembled in insect cells. Journal of Virology. 78, pp. 13285-13292.

Carducci, A., Verani, M., Battistini, R. and Pizzi, F. (2006). Epidemiological surveillance of human enteric viruses by monitoring of different environmental matrices.

Carvalho-Costa, F.A., Volotão, E.M., de Assis, R.M., Fialho, A.M., de Andrade, J.S., Rocha, L.N. et al. (2011). Laboratorybased rotavirus surveillance during the introduction of a vaccination program, Brazil, 2005-2009. The Pediatric Infectious Disease Journal. 30, pp. S35-S41. doi: 10.1097/INF.0b013e3181fefd5f.

Caul, E.O., Ashley, C.R., Darville, J.M. and Bridger, J.C. (1990). Group C rotavirus associated with fatal enteritis in a family outbreak. Journal of Medical Virology. 30, pp. 201-205. doi: 10.1002/jmv.1890300311.

CDC (2015). Centers for Disease Control: Department of Health and Human Services. 
CDC (2014). Rotavirus Home - Symptoms.

Chang, K.O., Parwani, A.V., Smith, D. and Saif, L.J. (1997). Detection of group B rotaviruses in fecal samples from diarrheic calves and adult cows and characterization of their VP7 genes. Journal of Clinical Microbiology. 35, pp. 2107-2110.

Chapron, C.D., Ballester, N.A. and Margolin, A.B. (2000). The detection of astrovirus in sludge biosolids using an integrated cell culture nested PCR technique. Journal of Applied Microbiology. 89, pp. 11-15.

Chasey, D. and Davies, P. (1984). Atypical rotaviruses in pigs and cattle. The Veterinary Record. 114, pp. 16-17.

Chigor, V.N. and Okoh, A.I. (2012). Quantitative RT-PCR detection of hepatitis A virus, rotaviruses and enteroviruses in the Buffalo River and source water dams in the Eastern Cape Province of South Africa. International Journal of Environmental Research and Public Health. 9(11), pp. 4017-4032. doi: 10.3390/ijerph9114017.

Chikhi-Brachet, R., Bon, F., Pothier, P., Nicolas, J.C., Flahault, A., Kohli, E. et al. (2002). Virus diversity in a winter epidemic of acute diarrhea in France. Journal of Clinical Microbiology. 40, pp. 4266-4272.

Chinsangaram, J., Akita, G.Y. and Osburn, B.I. (1994). Detection of bovine group B rotaviruses in feces by polymerase chain reaction. Journal of Veterinary Diagnostic Investigation. 6(3), pp. 302-307.

Clark, H.F., Bernstein, D.I., Dennehy, P.H., Offit, P., Pichichero, M., Treanor, J. et al. (2004). Safety, efficacy, and immunogenicity of a live, quadrivalent human-bovine reassortant rotavirusvaccine in healthy infants. Journal of Pediatrics. 144, pp. 558.

Clark, H.F., Burke, C.J., Volkin, D.B., Offit, P., Ward, R.L., Bresee, J.S. et al. (2003). Safety, immunogenicity and efficacy in healthy infants of G1 and G2 human reassortant rotavirus vaccine in a new stabilizer/buffer liquid formulation. The Pediatric Infectious Disease Journal. 22, pp. 914-920.

Cortese, M.M., Immergluck, L.C., Held, M., Jain, S., Chan, T., Grizas, A.P. et al. (2013). Effectiveness of monovalent and pentavalent rotavirus vaccine. Pediatrics. 132, pp. e25-e33. doi: 10.1542/peds.2012-3804.

Cox, M.J., James, V.L.A., Azevedo, R.S., Massad, E. and Medley, G.F. (1998). Infection with group C rotavirus in a suburban community in Brazil. Tropical Medicine and International Health. 3, pp. 891-895. doi: 10.1046/j.1365-3156.1998.00325.x.

Cubitt, W.D., Mitchell, D.K., Carter, M.J., Willcocks, M.M. and Holzel, H. (1999). Application of electronmicroscopy, enzyme immunoassay, and RT-PCR to monitor an outbreak of astrovirus type 1 in a paediatric bone marrow transplant unit. Journal of Medical Virology. 57, pp. 313-321.

Cunliffe, N.A., Dove, W., Gondwe, J.S., Thindwa, B.D., Greensill, J., Holmes, J.L. et al. (2002). Detection and characterisation of human astroviruses in children with acute gastroenteritis in Blantyre, Malawi. Journal of Medical Virology. 67, pp. 563-566.

Dóró, R., László, B., Martella, V., Leshem, E., Gentsch, J., Parashar, U. et al. (2014). Review of global rotavirus strain prevalence data from six years post vaccine licensure surveillance: is there evidence of strain selection from vaccine pressure?. Infection, Genetics and Evolution. 28, pp. 446-461.

Dai, Y.C., Xu, Q.H., Wu, X.B., Hu, G.F., Tang, Y.L., Li, J.D. et al. (2010). Development of real-time and nested RT-PCR to detect astrovirus and one-year survey of astrovirus in Jiangmen City, China. Archives of Virology. 155, pp. 977-982.

Dalton, R.M., Pastrana, E.P. and Sanchez-Fauquier, A. (2003). Vaccinia virus recombinant expressing an 87-kilodalton polyprotein that is sufficient to form astrovirus-like particles. Journal of Virology. 77, pp. 9094-9098.

Dalton, R.M., Roman, E.R., Negredo, A.A., Wilhelmi, I.D., Glass, R.I. and Sanchez-Fauquier, A. (2002). Astrovirus acute gastroenteritis among children in Madrid, Spain. The Pediatric Infectious Disease Journal. 21, pp. 1038-1041.

Das, B.K., Gentsch, J.R., Cicirello, H.G., Woods, P.A., Gupta, A., Ramachandran, M. et al. (1994). Characterization of rotavirus strains from newborns in New Delhi, India. Journal of Clinical Microbiology. 32, pp. 1820-1822. 
Da Silva, M.F., Fumian, T.M., de Assis, RM, Fialho, AM, Carvalho-Costa, FA, J de Andrade, da.Silva Ribe et al. (2017). VP7 and VP8* genetic characterization of group A rotavirus genotype G12P[8]: Emergence and spreading in the Eastern Brazilian coast in 2014. Journal of Medical Virology. 89(1), pp. 64-70.

Da Silva, M.F., Rose, TL, Gomez, MM, Carvalho-Costa, FA, Fialho, AM, Assis, R.M. et al. (2015). G1P[8] species A rotavirus over 27 years-pre- and post-vaccination eras-in Brazil: full genomic constellation analysis and no evidence for selection pressure by Rotarix ${ }^{\circledR}$ vaccine. Infection, Genetics and Evolution. 30, pp. 206-218.

De Benedictis, P., Schultz-Cherry, S., Burnham, A. and Cattoli, G. (2011). Astrovirus infections in humans and animals molecular biology, genetic diversity, and interspecies transmissions. Infection, Genetics and Evolution. 11, pp. 1529-1544.

De Bruin, E., Duizer, E., Vennema, H. and Koopmans, M.P. (2006). Diagnosis of Norovirus outbreaks by commercial ELISA or RT-PCR. Journal of Virological Methods. 137(2), pp. 259-264.

Deetz, T., Smith, E., Goyal, M., Gerba, C., Vollet, J., Tsai, L. et al. (1984). Occurrence of rota- and enteroviruses in drinking and environmental water in a developing nation. Water research. 18, pp. 567-571.

Dennehy, P.H. (2013). Treatment and prevention of rotavirus infection in children. Current Infectious Disease Reports. 15, pp. 242-250. doi: 10.1007/s11908-013-0333-5.

Dennehy, P.H., Brady, R.C., Halperin, S.A., Ward, R.L., Alvey, J.C., Fischer, F.H. et al. (2005). Comparative evaluation of safety and immunogenicity of two dosages of an oral live attenuated human rotavirus vaccine. The Pediatric Infectious Disease Journal. 24, pp. 481-488.

Divizia, M., Gabrieli, R. and Donia, D. (2004). Waterborne gastroenteritis outbreak in Albania.

Divizia, M., Gabrieli, R., Macaluso, A., Bagnato, B., Palombi, L., Buonomo, E. et al. (2005). Nucleotide correlation between HAV isolates from human patients and environmental samples. Journal of Medical Virology. 75, pp. 8-12.

Dubois, E., Le Guyader, F., Haugarreau, L., Kopecka, H., Cormier, M. and Pommepuy, M. (1997). Molecular epidemiological survey of rotaviruses in sewage by reverse transcriptase seminested PCR and restriction fragment length polymorphism assay. Applied and Environmental Microbiology. 63, pp. 1794-1800.

El-Senousy, M., Guix, S., Abid, I., Pinto, R.M. and Bosch, A. (2007). Removal of astrovirus from water and sewage treatment plants, evaluated by a competitive reverse transcription-PCR. Applied and Environmental Microbiology. 73, pp. 164-167.

El-Senousy, W.M., Osman, G.A. and Melegy, A.A. (2014). Survival of Adenovirus, Rotavirus, Hepatitis A Virus, Pathogenic Bacteria and Bacterial Indicators in Ground Water. World Applied Sciences Journal. 29, pp. 337-348.

El-Senousy, W.M., Ragab, A.M. and Handak, E.M. (2015). Prevalence of Rotaviruses Groups A and C in Egyptian Children and Aquatic Environment. Food and Environmental Virology. doi: 10.1007/s12560-015-9184-6.

Elamri, D.E., Aouni, M., Parnaudeau, S. and Le Guyader, F.S. (2006). Detection of human enteric viruses in shellfish collected in Tunisia. Letters in Applied Microbiology. 43, pp. 399-404.

Esona, M.D., Humphrey, C.D., Dennehy, P.H. and Jiang, B. (2008). Prevalence of group C rotavirus among children in Rhode Island, United States. Journal of Clinical Virology. 42, pp. 221-224.

Espinosa, A.C., Arias, C.F., Sánchez-Colón, S. and Mazari-Hiriart, M. (2009). Comparative study of enteric viruses, coliphages and indicator bacteria for evaluating water quality in a tropical high-altitude system. Environmental Health. 8, pp. 49.

Espinosa, A.C., Mazari-Hiriart, M., Espinosa, R., Maruri-Avidal, L., Méndez, E. and Arias, C.F. (2008). Infectivity and genome persistence of rotavirus and astrovirus in groundwater and surface water. Water Research. 42, pp. 2618-2628.

Estes, M.K. and Greenberg, H.B. (2013). Rotaviruses. Fields Virology. 2, pp. 1. 
Ferguson, A.S., Layton, A.C., Mailloux, B.J., Culligan, P.J., Williams, D.E., Smartt, A.E. et al. (2012). Comparison of fecal indicators with pathogenic bacteria and rotavirus in groundwater. Science of the Total Environment. 431, pp. 341-322.

Ferreira, F.F.M., Guimarães, F.R., Fumian, T.M., Victoria, M., Vieira, C.B., Luz, S. et al. (2009). Environmental dissemination of group A rotavirus: P-type, G-type and subgroup characterization. Water Science and Technology. 60, pp. 633-642.

Finkbeiner, S.R., Li, Y., Ruone, S. and Conrardy, C. (2009). Identification of a novel astrovirus (astrovirus VA1) associated with an outbreak of acute gastroenteritis. Journal of Virology. 83, pp. 10836-10839. doi: 10.1128/JVI.00998-09.

Fongaro, G., Nascimento, M.A. and Viancelli, A. (2012). Surveillance of human viral contamination and physicochemical profiles in a surface water lagoon.

Fumian, T.M., Leite, J.P., Castello, A.A., Gaggero, A., Caillou, M.S. and Miagostovich, M.P. (2010). Detection of rotavirus A in sewage samples using multiplex qPCR and an evaluation of the ultracentrifugation and adsorption-elution methods for virus concentration. Journal of Virological Methods. 170, pp. 42-6.

Fumian, T.M., Vieira, C.B., Leite, J.P. and Miagostovich, M.P. (2013). Assessment of burden of vírus agents in an urban sewage treatment plant in Rio de Janeiro, Brazil. Journal of Water and Health. 11, pp. 110-110.

Fumian, T.M., Leite, J.P.P., Rose, T.L., Prado, T. and Miagostovich, M.P. (2011). One year environmental surveillance of rotavirus species A (RVA) genotypes in circulation after the introduction of the Rotarix vaccine in Rio de Janeiro, Brazil. Water Research. 45, pp. 5755-5763. doi: 10.1016/j.watres.2011.08.039.

Gabrieli, R., Macaluso, A., Lanni, L., Saccares, S., Di Giamberardino, F., Cencioni, B. et al. (2007). Enteric viruses in molluscan shellfish. New Microbiology. 30, pp. 471-475.

Gaggero, A., O'Ryan, M., Noel, J.S., Glass, R.I., Monroe, S.S., Mamani, N. et al. (1998). Prevalence of astrovirus infection among Chilean children with acute gastroenteritis. Journal of Clinical Microbiology. 36, pp. 3691-3693.

Gajardo, R., Bouchriti, N., Pinto, R.M. and Bosch, A. (1995). Genotyping of rotaviruses isolated from sewage. Applied and Environmental Microbiology. 61, pp. 3460-3462.

Gallay, A., De Valk, H., Cournot, M., Ladeuil, B., Hemery, C., Castor, C. et al. (2006). A large multi-pathogen waterborne community outbreak linked to faecal contamination of a groundwater system, France, 2000. Clinical Microbiology and Infection. 12, pp. 561-570. doi: 10.1111/j.1469-0691.2006.01441.x.

Ganime, A.C., Carvalho-Costa, F.A., Mendonça, M.C., Vieira, C.B., Santos, M., Filho, R.Costa et al. (2012). Group A rotavirus detection on environmental surfaces in a hospital intensive care unit. American Journal of Infection Control. 40, pp. 544-547. doi: 10.1016/j.ajic.2011.07.017.

Glass, R.I., Woods, P., Gouvea, V., Gorziglia, M., Flores, J., Das, B.K. et al. (1992). Identification of group A rotavirus gene 4 types by polymerase chain reaction. Journal of Clinical Microbiology. 30, pp. 1365-1373.

Gofti-Laroche, L., Gratacap-Cavallier, B., Demanse, D., Genoulaz, O., Seigneurin, J.M. and Zmirou, D. (2003). Are waterborne astrovirus implicated in acute digestive morbidity (E.MI.R.A. study). Journal of Clinical Virology. 27, pp. 74-82.

Gouvea, V., Glass, R.I., Woods, P., Taniguchi, K., Clark, H.F., Forrester, B. et al. (1990). Polymerase chain reaction amplification and typing of rotavirus nucleic acid from stool specimens. Journal of Clinical Microbiology. 28, pp. 276-82.

Gouvea, V.S., Domingues, A.L., Naveca, F.G., Pedro, A.R. and Bevilacqua, C.C. (2007). Changing epidemiology of rotavirusrelated hospitalizations in rio de janeiro, Brazil, from 2002 to 2006. Open Virology Journal. 1, pp. 47-50.

Grassi, T., Bagordo, F., Idolo, A., Lugoli, F. and Gabutti, G. (2010). Rotavirus detection in environmental water samples by tangential flow ultrafiltration and RT-nested PCR. Environmental Monitoring and Assessment. 164, pp. 199-205.

Häfliger, D., Hübner, P. and Lüthy, J. (2000). Outbreak of viral gastroenteritis due to sewage-contaminated drinking water. 
International Journal of Food Microbiology. 54, pp. 123-126.

Hata, A., Katayama, H., Kitajima, M. and Furumai, H. (2015). Wastewater Analysis Indicates that Genetically Diverse Astroviruses, Including Strains Belonging to Novel Clades MLB and VA, Are Circulating within Japanese Populations. Applied and Environmental Microbiology. 81, pp. 4932-4939.

Heaton, P.M. and Ciarlet, M. (2007). Vaccines: the pentavalent rotavirus vaccine: discovery to licensure and beyond. Clinical Infectious Diseases. 45, pp. 1618-1624. doi: 10.1086/522997.

Heistad, A., Seidu, R., Flø, A., Paruch, A.M., Hanssen, J.F. and Stenström, T. (2009). Long-term hygienic barrier efficiency of a compact on-site wastewater treatment system. Journal of Environmental Quality. 38, pp. 2182-2188.

Hejkal, T.W., Smith, E.M. and Gerba, C.P. (1984). Seasonal occurrence of rotavirus in sewage. Applied and Environmental Microbiology. 47, pp. 588-590.

Herrmann, J.E., Nowak, N.A., Perron-Henry, D.M., Hudson, R.W., Cubitt, W.D. and Blacklow, N.R. (1990). Diagnosis of astrovirus gastroenteritis by antigen detection with monoclonal antibodies. Journal of Infectious Disease. 161, pp. $226-229$.

He, X., Wei, Y., Cheng, L., Zhang, D. and Wang, Z. (2012). Molecular detection of three gastroenteritis viruses in urban surface waters in Beijing and correlation with levels of fecal indicator bacteria. Environmental Monitoring and Assessment. 184(9), pp. 5563-5570. doi: 10.1007/s10661-011-2362-6.

He, X.Q., Cheng, L., Li, W., Xie, X.M. and Ma, M. (2008). Detection and distribution of rotavirus in municipal sewage treatment plants (STPs) and surface water in Beijing. Journal of Environmental Science and Health. Part A: Environmental Science and Engineering and Toxicology. 43(4), doi: 10.1080/10934520701795731.

He, X.Q., Cheng, L., Zhang, D.Y., Li, W., Xie, X.M. and Ma, M. (2009). First molecular detection of group A rotaviruses in drinking water sources in Beijing, China. Bulletin of Environmental Contamination and Toxicology. 83(1), pp. 120-124. doi: 10.1007/s00128-009-9708-6.

He, X.Q., Cheng, L., Zhang, D.Y., Li, W., Xie, X.M., Ma, M. et al. (2009). First molecular detection of group A rotaviruses in drinking water sources in Beijing, China. Bulletin of Environmental Contamination and Toxology. 83, pp. 120-124.

Hmaied, F., Keskes, S., Jebri, S., Amri, I., Yahya, M., Loisy-Hamon, F. et al. (2015). Removal of Rotavirus and Bacteriophages by Membrane Bioreactor Technology from Sewage. Current Opinion in Microbiology. 71, pp. 540-545.

Hoglund, C. (2001). Evaluation of microbial health risks associated with the reuse of source-separated human urine. Department of Biotechnology, Applied Microbiology. PhD, Royal Institute of Technology. Sweden.

Holtz, L.R., Bauer, I.K., Rajendran, P., Kang, G. and Wang, D. (2011). Astrovirus MLB1 is not associated with diarrhea in a cohort of Indian children. PLoS One. 6, pp. e28647.

Hopkins, R.S., Gaspard, G.B., Williams, Jr, F.P., Karlin, R.J., Cukor, G. and Blacklow, N.R. (1984). A community waterborne gastroenteritis outbreak: evidence for rotavirus as the agent. American Journal of Public Health. 74, pp. $263-265$.

Hot, D., Legeay, O., Jacques, J., Gantzer, C., Caudrelier, Y., Guyard, K. et al. (2003). Detection of somatic phages, infectious enteroviruses and enterovirus genomes as indicators of human enteric viral pollution in surface water. Water Research. 37, pp. 4703-4710.

Hung, T., Chen, G.M., Wang, C.G., Yao, H.L., Fang, Z.Y., Chao, T.X. et al. (1984). Waterborne outbreak of rotavirus diarrhoea in adults in China caused by a novel rotavirus. Lancet. 1, pp. 1139-1142.

ICTV (2015). International Committee on Taxonomy of Viruses, ICTV.

Iritani, N., Kaida, A., Abe, N., Kubo, H., Sekiguchi, J., Yamamoto, S. et al. (2014). Detection and genetic characterization of human enteric viruses in oyster-associated gastroenteritis outbreaks between 2001 and 2012 in Osaka City, Japan. Journal of Medical Virology. 86, pp. 2019-2025. 
Iturriza-Gómara, M.I., Wong, C., Blome, S., Desselberger, U. and Gray, J. (2002). Molecular characterization of VP6 genes of human rotavirus isolates, correlation of genogroups with subgroups and evidence of independent segregation. Journal of Virology. 76, pp. 6596-6601.

Iturriza-Gómara, M., Dallman, T., Bányai, K., Böttiger, B., Buesa, J., Diedrich, S. et al. (2009). Rotavirus surveillance in europe, 2005-2008: web-enabled reporting and real-time analysis of genotyping and epidemiological data. The Journal of Infectious Diseases. 200 Suppl, pp. S215-S221. doi: 10.1086/605049.

Jakab, F., Meleg, E., Bányai, K., Melegh, B., Tímár, L., Péterfai, J. et al. (2004). One-year survey of astrovirus infection in children with gastroenteritis in a large hospital in Hungary: occurrence and genetic analysis of astroviruses. Journal of Medical Virology. 74, pp. 71-77.

JE, W. and Mitchell, D.K. (2003). Astrovirus infection in children. Current Opinion in Infectious Disease. 16, pp. $247-253$.

Jin, M., Shan, J., Chen, Z., Guo, X., Shen, Z., Qiu, Z. et al. (2013). Chlorine dioxide inactivation of enterovirus 71 in water and its impact on genomic targets. Environmental Science and Technology. 47, pp. 4590-7. doi: 10.1021/es305282g.

John, D.E. and Rose, J.B. (2005). Review of factors affecting microbial survival in groundwater. Environmental Science and Technology. 1, pp. 7345-7356.

Julian, T.R. (2016). Environmental transmission of diarrheal pathogens in low and middle income countries. Environmental Science: Processes and Impacts. 18, pp. 944-955.

Kamel, A.H., Ali, M.A., El-Nady, H.G., Aho, S., Pothier, P. and Belliot, G. (2010). Evidence of the co-circulation of enteric viruses in sewage and in the population of Greater Cairo. Journal of Applied Microbiology. 108, pp. 1620-1629. doi: 10.1111/j.1365-2672.2009.04562.x.

Kapikian, A.Z. (2001). A rotavirus vaccine for prevention of severe diarrhoea of infants and young children: development, utilization and withdrawal. Novartis Foundation Symposium. 2, pp. 153-159.

Keller, R., Justino, J.F. and Cassini, S.T. (2013). Assessment of water and seafood microbiology quality in a mangrove region in Vitória, Brazil. Journal of Water Health. 11, pp. 573-580.

Keswick, B.H., Gerba, C.P., DuPont, H.L. and Rose, J.B. (984). Detection of enteric viruses in treated drinking water. Applied and Environmental Microbiology. 47, pp. 1290-1294.

Kitajima, M., Iker, B.C., Pepper, I.L. and Gerba, C.P. (2014). Relative abundance and treatment reduction of viruses during wastewater treatment processes-identification of potential viral indicators. The Science of the Total Environment. 488, pp. 290-296.

Kittigul, L., Khamoun, P., Sujirarat, D., Utrarachkij, F., Chitpirom, K., Chaichantanakit, N. et al. (2001). An improved method for concentrating rotavirus from water samples. Memorias do Instituto Oswaldo Cruz. 96, pp. 815-821.

Kittigul, L., Panjangampatthana, A., Rupprom, K. and Pombubpa, K. (2014). Genetic diversity of rotavirus strains circulating in environmental water and bivalve shellfish in Thailand. International Journal of Environmental Research and Public Health. 11, pp. 1299-1311. doi: 10.3390/ijerph110201299.

Kiulia, N.M., Mwenda, J.M., Nyachieo, A., Nyaundi, J.K., Steele, A.D. and Taylor, M.B. (2007). Astrovirus infection in young Kenyan children with diarrhoea. Journal of Tropical Pediatrics. 53, pp. 206-209.

Kiulia, N.M., Netshikweta, R., Page, N.A., Van Zyl, W.B., Kiraithe, M.M., Nyachieo, A. et al. (2010). The detection of enteric viruses in selected urban and rural river water and sewage in Kenya, with special reference to rotaviruses. Journal of Applied Microbiology. 109, pp. 818-828. doi: 10.1111/j.1365-2672.2010.04710.x.

Kiulia, N.M., Hofstra, N., Vermeulen, L.C., Obara, M.A., Medema, G. and Rose, J.B. (2015). Global occurrence and emission of rotaviruses to surface waters. Pathogens. 4, pp. 229-255. doi: 10.3390/pathogens4020229.

Kluge, M., Fleck, J.D., Soliman, M.C., Luz, R.B., Fabres, R.B., Comerlato, J. et al. (2014). Human adenovirus (HAdV), human 
enterovirus (hEV), and genogroup A rotavirus (GARV) in tap water in southern Brazil. Journal of Water and Health. 12, pp. 526-32. doi: 10.2166/wh.2014.202.

Koroglu, M., Yakupogullari, Y., Otlu, B., Ozturk, S., Ozden, M., Ozer, A. et al. (2011). A waterborne outbreak of epidemic diarrhea due to group A rotavirus in Malatya, Turkey. The New Microbiologica. 34, pp. 17-24.

Kukkula, M., Arstila, P. and Klossner, M.L. (1997). Waterborne outbreak of viral gastroenteritis. Scandinavian Journal of Infectious Diseases. 29(4), pp. 415-418. doi: 10.3109/00365549709011840.

Kumazaki, M. and Usuku, S. (2015). Nucleotide Correlations Between Rotavirus C Isolates in Clinical Samples from Outbreaks and in Sewage Samples. Food and Environmental Virology. 7, pp. 269-275.

Kurtz, J.B., Lee, T.W. and Parsons, A.J. (1980). The action of alcohols on rotavirus, astrovirus and enterovirus. Journal of Hospital Infection. 1, pp. 321-325.

Kuzuya, M., Hamano, M., Nishijima, M., Fujii, R., Ogura, H., Tanaka, M. et al. (2005). An outbreak of acute gastroenteritis caused by human group $\mathrm{C}$ rotavirus in a welfare institution in Okayama prefecture. Japanese Journal of Infectious Diseases. 58, pp. 255-257.

La Frazia, S., Ciucci, A., Arnoldi, F., Coira, M., Gianferretti, P., Angelini, M. et al. (2013). Thiazolides, a new class of antiviral agents effective against rotavirus infection, target viral morphogenesis, inhibiting viroplasm formation. Journal of Virology. 87, pp. 11096-11106.

Le Cann, P., Ranarijaona, S., Monpoeho, S., Le Guyader, F. and Ferré, V. (2004). Quantification of human astroviruses in sewage using real-time RT-PCR. Research in Microbiology. 155, pp. 11-15. doi: 10.1016/j.resmic.2003.09.013.

Le Guyader, F., Haugarreau, L., Miossec, L., Dubois, E. and Pommepuy, M. (2000). Three-year study to assess human enteric viruses in shellfish. Applied and Environmental Microbiology. 66, pp. 3241-3248.

Levy, K., Hubbard, A.E. and Eisenberg, J.N. (2009). Seasonality of rotavirus disease in the tropics: a systematic review and meta-analysis. International Journal of Epidemiology. 38, pp. 1487-1496. doi: 10.1093/ije/dyn260.

Li, D., Gu, A.Z., He, M., Shi, H.C.C. and Yang, W. (2009). UV inactivation and resistance of rotavirus evaluated by integrated cell culture and real-time RT-PCR assay. Water Research. 43, pp. 3261-3269. doi: 10.1016/j.watres.2009.03.044.

Li, D., Gu, A.Z., Zeng, S., Yang, W., He, M. and Shi, H. (2011). Evaluation of the infectivity, gene and antigenicity persistence of rotaviruses by free chlorine disinfection. Journal of Environmental Sciences. 23, pp. 1691-1698.

Li, D., Gu, A.Z., Zeng, S., Yang, W., He, M. and Shi, H. (2011). Evaluation of the infectivity, gene and antigenicity persistence of rotaviruses by free chlorine disinfection. Journal of Environmental Sciences. 23, pp. 1691-1698.

Linhares, A.C., Stupka, J.A., Ciapponi, A., Bardach, A.E., Glujovsky, D., Aruj, P.K. et al. (2011). Burden and typing of rotavirus group A in Latin America and the Caribbean: systematic review and meta-analysis. Reviews in Medical Virology. 21, pp. 89-109. doi: 10.1002/rmv.682.

Lizasoain, A., Tort, L.F., García, M., Gomez, M., Gomez, MM, Leite, J.P. et al. (2015). Environmental assessment reveals the presence of MLB-1 human astrovirus in Uruguay. Journal of Applied Microbiology. 119(3), doi: 10.1111/jam.12856.

Lizuka, S., Tabara, K., Kawamukai, A., Itogawa, H. and Hoshina, K. (2006). An outbreak of group C rotavirus infection in an elementary school in Shimane prefecture, Japan, February 2006. Japanese Journal of Infectious Diseases. 59, pp. 350-351.

Lodder, W.J., Vinjé, J., van De Heide, R., De Roda Husman, A.M., Leenen, E.J. and Koopmans, M.P. (1999). Molecular detection of Norwalk-like caliciviruses in sewage. Applied and Environmental Microbiology. 65, pp. 5624-5627.

Lycke, E., Blomberg, J., Berg, G., Eriksson, A. and Madsen, L. (1978). Epidemic acute diarrhoea in adults associated with infantile gastroenteritis virus. Lancet (London, England). 2, pp. 1056-1057. 
Müller, H. and Johne, R. (2007). Rotaviruses: diversity and zoonotic Potential-a brief review. Berliner Und Munchener Tierarztliche Wochenschrift. 120, pp. 108-112.

Méndez-Toss, M., Griffin, D.D., Calva, J., Contreras, J.F., Puerto, F.I., Mota, F. et al. (2004). Prevalence and genetic diversity of human astroviruses in Mexican children with symptomatic and asymptomatic infections. Journal of Clinical Microbiology. 42, pp. 151-157.

Méndez, E. and Arias, C.F. (2013). Astroviruses. Fields Virology. 1, pp. 609-628.

Méndez, E., Arias, C.F., Knipe, D.M., Howley, P.M., Griffin, D.E., Lamb, R.A. et al. (2007). Astroviruses. 5th ed. Lippincott Williams and Wilkins. Philadelphia, PA. pp. 981-1000.

Madeley, C.R. and Cosgrove, B.P. (1975). Letter: $28 \mathrm{~nm}$ particles in faeces in infantile gastroenteritis. Lancet. 2, pp. 451-452.

Martella, V., Bányai, K., Matthijnssens, J., Buonavoglia, C. and Ciarlet, M. (2010). Zoonotic aspects of rotaviruses. Veterinary Microbiology. 140, pp. 246-255. doi: 10.1016/j.vetmic.2009.08.028.

Martinelli, D., Prato, R., Chironna, M., Sallustio, A., Caputi, G., Conversano, M. et al. (2007). Large outbreak of viral gastroenteritis caused by contaminated drinking water in Apulia, Italy, May-October 2006. Euro Surveillance. 12, pp. E070419.

Matthijnssens, J., Miño, S., Papp, H., Potgieter, C., Novo, L., Heylen, E. et al. (2012). Complete molecular genome analyses of equine rotavirus A strains from different continents reveal several novel genotypes and a largely conserved genotype constellation. Journal of General Virology. 93, pp. 866-875.

Matthijnssens, J., Taraporewala, Z.F., Yang, H., Rao, S., Yuan, L., Cao, D. et al. (2010). Simian rotaviruses possess divergent gene constellations that originated from interspecies transmission and reassortment. Journal of Virology. 84, pp. 2013-2026.

Matthijnssens, J., Ciarlet, M., McDonald, S.M., Attoui, H., Bányai, K., Brister, J.R. et al. (2011). Uniformity of rotavirus strain nomenclature proposed by the Rotavirus Classification Working Group RCWG. Archives of Virology. 156, pp. 1397-1413. doi: 10.1007/s00705-011-1006-z.

Matthijnssens, J. and Ranst, M. (2012). Genotype constellation and evolution of group A rotaviruses infecting humans. Current Opinion in Virology. 2, pp. 426-433.

Maunula, L., Svensson, L. and Bonsdorff, C.H. (1992). A family outbreak of gastroenteritis caused by group C rotavirus. Archives of Virology. 124, pp. 269-278. doi: 10.1007/BF01309808.

McClain, B., Settembre, E., Temple, B.R., Bellamy, A.R. and Harrison, S.C. (2010). X-ray crystal structure of the rotavirus inner capsid particle at 3.8 A resolution. Journal of Molecular Biology. 397, pp. 587-599.

Mehnert, D.U. and Stewien, K.E. (1993). Detection and distribution of rotavirus in raw sewage and creeks in Sao Paulo, Brazil. Applied and Environmental Microbiology. 59, pp. 140-143.

Mellou, K., Katsioulis, A., Potamiti-Komi, M., Pournaras, S., Kyritsi, M., Katsiaflaka, A. et al. (2014). A large waterborne gastroenteritis outbreak in central Greece, March 2012: challenges for the investigation and management. Epidemiology and Infection. 142, pp. 40-50. doi: 10.1017/S0950268813000939.

Melnick, J.L., Gerba, C.P. and Wallis, C. (1978). Viruses in water. Bulletin of the World Health Organization. 56, pp. 499-508.

Menon, S., Santosham, M., Almeido-Hill, J., Reid, R., Sack, R.B. and Comstock, G.W. (1990). Rotavirus diarrhoea in Apache children: a case-control study. International Journal of Epidemiology. 19, pp. 715-721.

Merck (2007). RotaTeq (prescribing information). Whitehouse Station, NJ: Merck and Co Inc, 2007. 
Miagostovich, M., Ferreira, F., Guimarães, F., Fumian, T., Diniz-Mendes, L., Luz, S. et al. (2008). Molecular detection and characterization of gastroenteritis viruses occurring naturally in the stream waters of Manaus, central Amazonia, Brazil. Applied and Environmental Microbiology. 74(2), pp. 375-382. doi: 10.1128/AEM.00944-07.

Miagostovich, M.P., Guimarães, F.R.R., Vieira, C.B., Fumian, T.M., da Gama, N.P., Victoria, M. et al. (2014). Assessment of water quality in a border region between the Atlantic forest and an urbanised area in Rio de Janeiro, Brazil. Food and Environmental Virology. 6, pp. 110-115. doi: 10.1007/s12560-014-9146-4.

Ming, H., Fan, J., Wu, L., Yue, L., Gao, X. and Liang, Y. (2014). Contamination of typical human enteric viruses in economic shellfish along the Chinese coast. Wei sheng wu xue bao= Acta microbiologica Sinica. 54, pp. 69-79.

Moreno, S., Alvarado, M.V.V., Bermúdez, A. and Gutiérrez, M.F.F. (2009). Phylogenetic analysis indicates human origin of rotavirus and hepatitis A virus strains found in the drinking water of western Colombia. Biomedica : Revista del Instituto Nacional de Salud. 29, pp. 209-217.

Mwenda, J.M., Peenze, I., Omollo, E., Galo, M. and Steele, A.D. (2003). Human group C rotaviruses identified in Kenya. East African Medical Journal. 80, pp. 73-76.

Ng, T.F., Marine, R., Wang, C., Simmonds, P., Kapusinszky, B., Bodhidatta, L. et al. (2012). High variety of known and new RNA and DNA viruses of diverse origins in untreated sewage. Journal of Virology. 86, pp. 12161-12175.

Nilsson, M., Svenungsson, B., Hedlund, K.O., Uhnoo, I., Lagergren, A., Akre, T. et al. (2000). Incidence and genetic diversity of group C rotavirus among adults. Journal of Infectious Disease. 182, pp. 678-684. doi: 10.1086/315772.

Noel, J.S., Lee, T.W., Kurtz, J.B., Glass, R.I. and Monroe, S.S. (1995). Typing of human astroviruses from clinical isolates by enzyme immunoassay and nucleotide sequencing. Journal of Clinical Microbiology. 33, pp. 797-801.

O'Ryan, M. (2007). Rotarix (RIX4414): an oral human rotavirus vaccine. Expert Review of Vaccines. 6, pp. 11-19.

Otto, P., Schulze, P. and Herbst, W. (1999). Demonstration of group C rotaviruses in fecal samples of diarrheic dogs in Germany. Archives of Virology. 144, pp. 2467-2473.

Pager, C.T. and Steele, A.D. (2002). Astrovirus-associated diarrhea in South African adults. Clinical infectious diseases : an official publication of the Infectious Diseases Society of America. 35, pp. 1452-1453.

Patel, M.M., Steele, D., Gentsch, J.R., Wecker, J., Glass, R.I. and Parashar, U.D. (2011). Real-world impact of rotavirus vaccination. The Pediatric Infectious Disease Journal. 30, pp. S1-S5. doi: 10.1097/INF.0b013e3181fefa1f.

PATH (2014). RotaFlesh issues 2014. 2015, PATH.

Pativada, M., Nataraju, S.M., Ganesh, B., Rajendran, K., Ramamurthy, T., Ganguly, S. et al. (2012). Emerging trends in the epidemiology of human astrovirus infection among infants, children and adults hospitalized with acute watery diarrhea in Kolkata, India. Infection, Genetics and Evolution. 12, pp. 1685-1693.

Paulke-Korinek, M., Kundi, M., Rendi-Wagner, P., de Martin, A., Eder, G., Schmidle-Loss, B. et al. (2011). Herd immunity after two years of the universal mass vaccination program against rotavirus gastroenteritis in Austria. Vaccine. 29(15), pp. 2791-2796. doi: 10.1016/j.vaccine.2011.01.104.

Paul, S.K., Hossain, M.A., Mahmud, M.C., Ahmed, S., Hossain, M.A., Nandi, A.K. et al. (2011). Instability of human rotavirus $\mathrm{G}$ genotypes circulating in a rural area of Bangladesh. Mymensignh Medical Journal. 20, pp. 1-8.

Phua, K.B., Quak, S.H., Lee, B.W., Emmanuel, S.C., Goh, P., Han, H.H. et al. (2005). Evaluation of RIX4414, a live, attenuated rotavirus vaccine, in a randomized, double-blind, placebo-controlled phase 2 trial involving 2464 Singaporean infants. The Journal of Infectious Diseases. 192 Suppl, pp. S6-SS16. doi: 10.1086/431511.

Podewils, L.J., Blevins, Z.L., Hagenbuch, M., Itani, D., Burns, A., Otto, C. et al. (2007). Outbreak of norovirus illness associated with a swimming pool. Epidemiology and Infection. 135(5), pp. 827-833. 
Prado, T., Fumian, T.M., Miagostovich, M.P. and Gaspar, A.M. (2012). Monitoring the hepatitis A virus in urban wastewater from Rio de Janeiro, Brazil. Transactions of the Royal Society of Tropical Medicine and Hygiene. 106, pp. 104-109.

Prado, T., Wde, G.C., Gaspar, A.M. and Miagostovich, M.P. (2013). The efficiency of concentration methods used to detect enteric viruses in anaerobically digested sludge. Memorias do Instituto Oswaldo Cruz. 108(1), pp. 77-83.

Prado, T., Silva, D.M., Guilayn, W.C., Rose, T.L., Gaspar, A.M. and Miagostovich, M.P. (2011). Quantification and molecular characterization of enteric viruses detected in effluents from two hospital wastewater treatment plants. Water Research. 45, pp. 1287-1297. doi: 10.1016/j.watres.2010.10.012.

Prevost, B., Lucas, F.S., Goncalves, A., Richard, F., Moulin, L. and Wurtzer, S. (2015). Large scale survey of enteric viruses in river and waste water underlines the health status of the local population. Environment International. 79, pp. 42-50.

Pusch, D., Oh, D.Y., Wolf, S., Dumke, R., Schröter-Bobsin, U., Höhne, M. et al. (2005). Detection of enteric viruses and bacterial indicators in German environmental waters. Archives of Virology. 150, pp. 929-947.

Quan, P.L., Wagner, T.A., Briese, T., Torgerson, T.R., Hornig, M., Tashmukhamedova, A. et al. (2010). Astrovirus encephalitis in boy with X-linked agammaglobulinemia. Emerging Infectious Diseases. 16, pp. 918-925.

Quiroz-Santiago, C., Vázquez-Salinas, C., Natividad-Bonifacio, I., Barrón-Romero, B.L. and Quiñones-Ramírez, E.I. (2014). Rotavirus G2P4 detection in fresh vegetables and oysters in Mexico City. Journal of Food Protection. 77, pp. 1953-1959. doi: 10.4315/0362-028X.JFP-13-426.

Räsänen, S., Lappalainen, S., Kaikkonen, S., Hämäläinen, M., Salminen, M. and Vesikari, T. (2010). Mixed viral infections causing acute gastroenteritis in children in a waterborne outbreak. Epidemiology and Infection. 138, pp. 1227-34.

Ramani, S., Sankaran, P., Arumugam, R., Sarkar, R., Banerjee, I., Mohanty, I. et al. (2010). Comparison of viral load and duration of virus shedding in symptomatic and asymptomatic neonatal rotavirus infections. Journal of Medical Virology. 82, pp. 1803-1807. doi: 10.1002/jmv.21872.

Raphael, R.A., Sattar, S.A. and Springthorpe, V.S. (1985). Long-term survival of human rotavirus in raw and treated river water. Canadian Journal of Microbiology. 31, pp. 124-34.

Ratcliff, R.M., Doherty, J.C. and Higgins, G.D. (2002). Sensitive detection of RNA viruses associated with gastroenteritis by a hanging-drop single-tube nested reverse transcription-PCR method. Journal of Clinical Microbiology. 40, pp. 4091-4099.

Rha, B., Tate, J.E., Payne, D.C., Cortese, M.M., Lopman, B.A., Curns, A.T. et al. (2014). Effectiveness and impact of rotavirus vaccines in the United States - 2006-2012. Expert Review of Vaccines. 13, pp. 365-376. doi: 10.1586/14760584.2014.877846.

Rigotto, C., Victoria, M., Moresco, V., Kolesnikovas, C.K., Corrêa, A.A., Souza, D.S.M. et al. (2010). Assessment of adenovirus, hepatitis A virus and rotavirus presence in environmental samples in Florianopolis, South Brazil. Journal of Applied Microbiology. 109, pp. 1979-1987.

Riou, P., Le Saux, J.C., Dumas, F., Caprais, M.P., Le Guyader, S.F. and Pommepuy, M. (2007). Microbial impact of small tributaries on water and shellfish quality in shallow coastal areas. Water Research. 41, pp. 2774-2786.

Rivera, R., Nollens, H.H., Venn-Watson, S., Gulland, F.M. and Wellehan, Jr, J.F. (2010). Characterization of phylogenetically diverse astroviruses of marine mammals. Journal of General Virology. 91, pp. 166-173.

Rodger, S.M., Bishop, R.F. and Holmes, I.H. (1982). Detection of a rotavirus-like agent associated with diarrhea in an infant. Journal of Clinical Microbiology. 16, pp. 724-726.

Rodríguez-Díaz, J., Querales, L., Caraballo, L., Vizzi, E., Liprandi, F., Takiff, H. et al. (2009). Detection and characterization of waterborne gastroenteritis viruses in urban sewage and sewage-polluted river waters in Caracas, Venezuela. Applied and Environmental Microbiology. 75, pp. 387-394. doi: 10.1128/AEM.02045-08.

Rogers, M., Weinstock, D.M., Eagan, J., Kiehn, T., Armstrong, D. and Sepkowitz, K.A. (2000). Rotavirus outbreak on a 
pediatric oncology floor: possible association with toys. American Journal of Infection Control. 28, pp. 378-380. doi: 10.1067/mic.2000.109908.

Rohayem, J., Dumke, R., Jaeger, K., Schröter-Bobsin, U., Mogel, M., Kruse, A. et al. (2006). Assessing the risk of transmission of viral diseases in flooded areas: viral load of the River Elbe in Dresden during the flood of August 2002. Intervirology. 49, pp. 370-376.

Rossignol, J.F., Abu-Zekry, M., Hussein, A. and Santoro, M.G. (2006). Effect of nitazoxanide for treatment of severe rotavirus diarrhoea: randomised double-blind placebo-controlled trial. Lancet. 368, pp. 124-129. doi: 10.1016/S0140-6736(06)68852-1.

Ruggeri, F.M., Bonomo, P., Ianiro, G., Battistone, A., Delogu, R., Germinario, C. et al. (2015). Rotavirus genotypes in sewage treatment plants and in children hospitalized with acute diarrhea in Italy in 2010 and 2011. Applied and Environmental Microbiology. 81, pp. 241-249. doi: 10.1128/AEM.02695-14.

Ruiz-Palacios, G.M., Guerrero, M.L., Bautista-Márquez, A., Ortega-Gallegos, H., Tuz-Dzib, F., Reyes-González, L. et al. (2007). Dose response and efficacy of a live, attenuated human rotavirus vaccine in Mexican infants. Pediatrics. 120, pp. e253-e261. doi: 10.1542/peds.2006-2630.

Ruiz-Palacios, G.M., Pérez-Schael, I., Velázquez, F.R., Abate, H., Breuer, T., Clemens, S.A.C. et al. (2006). Safety and efficacy of an attenuated vaccine against severe rotavirus gastroenteritis. The New England Journal of Medicine. 354, pp. 11-22. doi: 10.1056/NEJMoa052434.

Rutjes, S.A., Lodder, W.J., van Leeuwen, A.D. and De Roda Husman, A.M. (2009). Detection of infectious rotavirus in naturally contaminated source waters for drinking water production. Journal of Applied Microbiology. 107, pp. 97-105.

Saif, L.J., Bohl, E.H., Theil, K.W., Cross, R.F. and House, J.A. (1980). Rotavirus-like, calicivirus-like, and 23-nm virus-like particles associated with diarrhea in young pigs. Journal of Clinical Microbiology. 12, pp. 105-111.

Salinas, B., Pérez Schael, I., Linhares, A.C., Ruiz Palacios, G.M., Guerrero, M.L., Yarzábal, J.P. et al. (2005). Evaluation of safety, immunogenicity and efficacy of an attenuated rotavirus vaccine, RIX4414: A randomized, placebo-controlled trial in Latin American infants. The Pediatric Infectious Disease Journal. 24, pp. 807-816.

Sanekata, T., Ahmed, M.U., Kader, A., Taniguchi, K. and Kobayashi, N. (2003). Human group B rotavirus infections cause severe diarrhea in children and adults in Bangladesh. Journal of Clinical Microbiology. 41, pp. 2187-2190.

Sattar, S.A., Ijaz, M.K., Johnson-Lussenburg, C.M. and Springthorpe, V.S. (1984). Effect of relative humidity on the airborne survival of rotavirus SA11. Applied and Environmental Microbiology. 47, pp. 879-881.

Sattar, S.A., Jacobsen, H., Rahman, H., Cusack, T.M. and,. (1994). Interruption of rotavirus spread through chemical disinfection. Infection Control and Hospital Epidemiology. 15, pp. 751-756.

Sdiri-Loulizi, K., Hassine, M., Aouni, Z., Gharbi-Khelifi, H., Chouchane, S., Sakly, N. et al. (2010). Detection and molecular characterization of enteric viruses in environmental samples in Monastir, Tunisia between January 2003 and April 2007. Journal of Applied Microbiology. 109, pp. 1093-1104. doi: 10.1111/j.1365-2672.2010.04772.x.

Shen, Z., Wang, G., Zhang, W., Qian, F., Li, Y., Zhang, M. et al. (2013). Rotavirus infection and its genetic characterization in non-hospitalized adults with acute gastroenteritis in Shanghai, China. Archives of Virology. 158, pp. 1671-1677.

Snodgrass, D.R., Herring, A.J., Campbell, I., Inglis, J.M. and Hargreaves, F.D. (1984). Comparison of atypical rotaviruses from calves, piglets, lambs and man. The Journal of General Virology. 65 ( Pt 5), pp. 909-914.

Solodovnikov, I.P., Nechiporenko, N.G., Tregub, A.V., Kuz'mina, N.A. and Balandin, A.I. (1989). The epidemiology of rotavirus gastroenteritis. Zhurnal Mikrobiologii, Epidemiologii, i Immunobiologii. 10, pp. 43-8.

Souza, D.F.C., Kisielius, J.J., Ueda, M. and Gabbay, Y.B. (1998). An outbreak of group C rotavirus gastroenteritis among adults living in Valentim Gentil, São Paulo state, Brazil. Journal of Diarrhoeal Diseases Research. 16, pp. 59-65. doi: 10.2307/23498490. 
Steele, M. and Odumeru, J. (2004). Irrigation water as source of foodborne pathogens on fruit and vegetables. Journal of Food Protection. 67, pp. 2839-2849.

Steinmann, J. and Havemeister, G. (1982). Elimination of bacteria and viruses by flocculation in treated sewage. Zentralblatt für Bakteriologie, Mikrobiologie und Hygiene. 1 Abt. Originale B. 176, pp. 546-552.

Steyer, A., Torkar, K.G., Gutiérrez-Aguirre, I. and Poljsak-Prijatelj, M. (2011). High prevalence of enteric viruses in untreated individual drinking water sources and surface water in Slovenia. International Journal of Hygiene and Environmental Health. 214, pp. 392-398.

Sun, J., Xiao, K., Yan, X., Liang, P., Shen, Y.X., Zhu, N. et al. (2015). Membrane bioreactor vs. oxidation ditch: full-scale long-term performance related with mixed liquor seasonal characteristics. Process Biochemistry. 50, pp. 2224-2233. doi: 10.1016/j.procbio.2015.09.010.

Tate, J.E., Burton, A.H., Boschi-Pinto, C., Steele, A.D., Duque, J., Parashar, U.D. et al. (2012). 2008 estimate of worldwide rotavirus-associated mortality in children younger than 5 years before the introduction of universal rotavirus vaccination programmes: a systematic review and meta-analysis. Lancet Infectious Diseases. 12, pp. 136-141. doi: 10.1016/s1473-3099(11)70253-5.

Tate, J.E., Burton, A.H., Boschi-Pinto, C. and Parashar, U.D. (2016). Global, Regional, and National Estimates of Rotavirus Mortality in Children <5 Years of Age, 2000-2013. Clinical Infectious Diseases. 1(62 Suppl 2), pp. S96-S105. doi: 10.1093/cid/civ1013.

Teran, C.G., Teran-Escalera, C.N. and Villarroel, P. (2009). Nitazoxanide vs. probiotics for the treatment of acute rotavirus diarrhea in children: a randomized, single-blind, controlled trial in Bolivian children. International Journal of Infectious Diseases. 13, pp. 518-523. doi: 10.1016/j.ijid.2008.09.014.

Theil, K.W., Grooms, D.L., McCloskey, C.M. and Redman, D.R. (1995). Group B rotavirus associated with an outbreak of neonatal lamb diarrhea. Journal of Veterinary Diagnostic Investigation. 7, pp. 148-150.

Torres-Medina, A. (1987). Isolation of an atypical rotavirus causing diarrhea in neonatal ferrets. Laboratory Animal Science. 37, pp. 167-171.

Tort, L.F., Victoria, M., Lizasoain, A., García, M., Berois, M., Cristina, J. et al. (2015). Detection of Common, Emerging and Uncommon VP4, and VP7 Human Group A RotavirusGenotypes from Urban Sewage Samples in Uruguay. Food and Environmental Virology. 7, pp. 342-353.

Tsunemitsu, H., Morita, D., Takaku, H., Nishimori, T., Imai, K. and Saif, L.J. (1999). First detection of bovine group B rotavirus in Japan and sequence of its VP7 gene. Archives of Virology. 144, pp. 805-815.

Tsunemitsu, H., Saif, L.J., Jiang, B.M., Shimizu, M., Hiro, M., Yamaguchi, H. et al. (1991). Isolation, characterization, and serial propagation of a bovine group $\mathrm{C}$ rotavirus in a monkey kidney cell line (MA104). Journal of Clinical Virology. 29, pp. 2609-2613.

Van Zyl, W.B., Page, N.A., Grabow, W.O.K., Steele, A.D. and Taylor, M.B. (2006). Molecular epidemiology of group A rotaviruses in water sources and selected raw vegetables in southern Africa. Applied and Environmental Microbiology. 72, pp. 4554-4560.

Vecchia, A.D., Fleck, J.D., Kluge, M. and Comerlato, J. (2012). Assessment of enteric viruses in a sewage treatment plant located in Porto Alegre, southern Brazil. Brazilian Journal of Biology. 72(4), pp. 839-846. doi: 10.1590/S1519-69842012000500009.

Velázquez, F.R. (2009). Protective effects of natural rotavirus infection. The Pediatric Infectious Disease Journal. 28, pp. S54-S56. doi: 10.1097/INF.0b013e3181967c03.

Vesikari, T., Karvonen, A., Puustinen, L., Zeng, S.Q., Szakal, E.D., Delem, A. et al. (2004). Efficacy of RIX4414 live attenuated human rotavirus vaccine in Finnish infants. Pediatric Infectious Disease Journal. 23, pp. 937-943. 
Vesikari, T., Matson, D.O., Dennehy, P., Damme, P., Santosham, M., Rodriguez, Z. et al. (2006). Safety and efficacy of a pentavalent human $\square$ bovine (WC3) reassortant rotavirus vaccine. New England Journal of Medicine. 354, pp. 23-33.

Victoria, M., Guimarães, F.R., Fumian, T.M., Ferreira, F.F., Vieira, C.B., Shubo, T. et al. (2010). One year monitoring of norovirus in a sewage treatment plant in Rio de Janeiro, Brazil. Journal of Water Health. 8, pp. 158-165.

Victoria, M., Tort, L.F., García, M., Lizasoain, A., Maya, L., Leite, J.P. et al. (2014). Assessment of gastroenteric viruses from wastewater directly discharged into Uruguay River, Uruguay. Food and Environmental Virology. 6, pp. 116-124. doi: 10.1007/s12560-014-9143-7.

Vieira, C.B., de Abreu Corrêa, A., de Jesus, M.S., Luz, S.L., Wyn-Jones, P., Kay, D. et al. (2016). Viruses Surveillance Under Different Season Scenarios of the Negro River Basin, Amazonia, Brazil. Food and Environmental Virology. 8, pp. 57-69.

Vieira, C.B., Mendes, A.C., Guimarães, F.R., Fumian, T.M., Leite, J.P., Gaspar, A.M. et al. (2012). Detection of enteric viruses in recreational waters of an urban lagoon in the city of Rio de Janeiro, Brazil. Memórias do Instituto Oswaldo Cruz. 107, pp. 778-784.

Villena, C., El-Senousy, W.M., Abad, F.X., Pintó, R.M. and Bosch, A. (2003). Group A rotavirus in sewage samples from Barcelona and Cairo: emergence of unusual genotypes. Applied and Environmental Microbiology. 69, pp. 3919-3923. doi: 10.1128/AEM.69.7.3919-3923.2003.

Villena, C., El-Senousy, W.M., Abad, F.X., Pintó, R.M. and Bosch, A. (2003). Group A rotavirus in sewage samples from Barcelona and Cairo: emergence of unusual genotypes. Applied and Environmental Microbiology. 69, pp. 3919-3923. doi: 10.1128/AEM.69.7.3919-3923.2003.

Walker, C.L., Rudan, I., Liu, L., Nair, H., Theodoratou, E., Bhutta, Z.A. et al. (2013). Global burden of childhood pneumonia and diarrhoea. The Lancet. 381, pp. 1405-1416.

Ward, R.L., Kirkwood, C.D., Sander, D.S., Smith, V.E., Shao, M., Bean, J.A. et al. (2006). Reductions in cross-neutralizing antibody responses in infants after attenuation of the human rotavirus vaccine candidate 89-12. The Journal of Infectious Diseases. 194, pp. 1729-1736. doi: 10.1086/509623.

Ward, R.L. and Ashley, C.S. (1980). Effects of wastewater sludge and its detergents on the stability of rotavirus. Applied and Environmental Microbiology. 39, pp. 1154-1158.

Westrell, T., Schönning, C., Stenström, T.A. and Ashbolt, N.J. (2004). QMRA (quantitative microbial risk assessment) and HACCP (hazard analysis and critical control points) for management of pathogens in wastewater and sewage sludge treatment and reuse. Water Science and Technology. 50, pp. 23-30.

WHO (2013). Rotavirus vaccines WHO position paper. World Health Organization - Technical Report Series.

WHO (2009). Weekly epidemiological record, No 23, 5 June 2009. World Health Organization (WHO).

Wickelgren, I. (2000). How rotavirus causes diarrhea. Science. 287, pp. 409,411.

Wilhelmi, I., Roman, E. and Sanchez-Fauquier, A. (2003). Viruses causing gastroenteritis. Clinical microbiology and infection : the official publication of the European Society of Clinical Microbiology and Infectious Diseases. 9, pp. 247-262.

Willcocks, M.M., Ashton, N., Kurtz, J.B., Cubitt, W.D. and Carter, M.J. (1994). Cell culture adaptation of astrovirus involves a deletion. Journal of Virology. 68, pp. 6057-6058.

Wolfaardt, M., Kiulia, N.M., Mwenda, J.M. and Taylor, M.B. (2011). Evidence of a recombinant wild-type human astrovirus strain from a Kenyan child with gastroenteritis. Journal of Clinical Microbiology. 49, pp. 728-731.

Wong, M., Kumar, L., Jenkins, T.M., Xagoraraki, I., Phanikumar, M.S. and Rose, J.B. (2009). Evaluation of public health risks at recreational beaches in Lake Michigan via detection of enteric viruses and a human-specific bacteriological marker. Water Research. 43, pp. 1137-1149. 
Wunderli, W., Meerbach, A., Güngör, T., Berger, C., Greiner, O., Caduff, R. et al. (2011). Astrovirus infection in hospitalized infants with severe combined immunodeficiency after allogeneic hematopoietic stem cell transplantation. PLoS one. 6, pp. e27483.

Yang, J.H., Kobayashi, N., Wang, Y.H., Zhou, X., Li, Y., Zhou, D.J. et al. (2004). Phylogenetic analysis of a human group B rotavirus WH-1 detected in China in 2002. Journal of Medical Virology. 74, pp. 662-667.

Yokoi, H., Kitahashi, T., Tanaka, T. and Utagawa, E. (2001). Detection of astrovirus RNA from sewage works, seawater and native oysters samples in Chiba City, Japan using reverse transcription-polymerase chain reaction. Kansenshogaku Zasshi. 75, pp. 263-269.

Zeng, S.Q., Halkosalo, A., Salminen, M., Szakal, E.D., Puustinen, L. and Vesikari, T. (2008). One-step quantitative RT-PCR for the detection of rotavirus in acute gastroenteritis. Journal of Virological Methods. 153, pp. 238-240.

Zhang, Z., Mitchell, D.K., Afflerbach, C., Jakab, F., Walter, J., Zhang, Y.J. et al. (2006). Quantitation of human astrovirus by real-time reverse-transcription-polymerase chain reaction to examine correlation with clinical illness. Journal of Virological Methods. 134, pp. 190-196.

Zhou, N., Lin, X., Wang, S., Wang, H., Li, W., Tao, Z. et al. (2014). Environmental surveillance for human astrovirus in Shandong Province, China in 2013. Scientific Reports. 4, pp. 7539. 